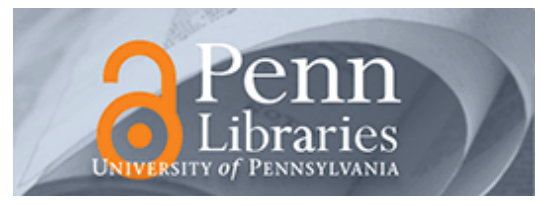

University of Pennsylvania

ScholarlyCommons

Management Papers

Wharton Faculty Research

\title{
2-2011
}

\section{Are U.S. CEOs Paid More Than U.K. CEOs? Inferences From Risk- Adjusted Pay}

Martin J. Conyon

John E. Core

Wayne R. Guay

University of Pennsylvania

Follow this and additional works at: https://repository.upenn.edu/mgmt_papers

Part of the Business Administration, Management, and Operations Commons

\section{Recommended Citation}

Conyon, M. J., Core, J. E., \& Guay, W. R. (2011). Are U.S. CEOs Paid More Than U.K. CEOs? Inferences From Risk-Adjusted Pay. The Review of Financial Studies, 24 (2), 402-438. http://dx.doi.org/10.1093/rfs/ hhq112

This paper is posted at ScholarlyCommons. https://repository.upenn.edu/mgmt_papers/89

For more information, please contact repository@pobox.upenn.edu. 


\title{
Are U.S. CEOs Paid More Than U.K. CEOs? Inferences From Risk-Adjusted Pay
}

\begin{abstract}
We compute and compare risk-adjusted CEO pay in the United States and United Kingdom, where the risk adjustment is based on estimated risk premiums stemming from the equity incentives borne by CEOs. Controlling for firm and industry characteristics, we find that U.S. CEOs have higher pay, but also bear much higher stock and option incentives than U.K. CEOs. Using reasonable estimates of risk premiums, we find that risk-adjusted U.S. CEO pay does not appear to be large compared to that of U.K. CEOs. We also examine differences in pay and equity incentives between a sample of non-U.K. European CEOs and a matched sample of U.S. CEOs, and find that risk-adjusting pay may explain about half of the apparent higher pay for U.S. CEOs.
\end{abstract}

\section{Keywords}

CEO compensation, incentives, risk aversion, corporate governance, international comparisons

Disciplines

Business Administration, Management, and Operations 


\title{
Are US CEOs Paid More Than UK CEOs? Inferences From Risk-Adjusted Pay
}

\author{
Martin J. Conyon* \\ The Wharton School \\ The University of Pennsylvania \\ conyon@wharton.upenn.edu \\ John E. Core \\ The Wharton School \\ The University of Pennsylvania \\ jcore@wharton.upenn.edu \\ Wayne R. Guay \\ The Wharton School \\ The University of Pennsylvania \\ guay@wharton.upenn.edu
}

First draft: April, 2005

Current draft: April 6, 2009

\begin{abstract}
We compute and compare risk-adjusted pay for US and UK CEOs, where the adjustment is based on estimated risk premiums stemming from the equity incentives borne by CEOs. Controlling for firm and industry characteristics, we find that US CEOs have higher pay, but also bear much higher stock and option incentives than UK CEOs. Using reasonable estimates of risk premiums, we find that risk-adjusted US CEO pay does not appear large compared to that of UK CEOs. We also examine differences in pay and equity incentives between a sample of non-UK European CEOs and a matched sample of US CEOs, and find that risk-adjusting pay may explain about half of the apparent higher pay for US CEOs.
\end{abstract}

(JEL G31, G34, M41)

Keywords: CEO compensation, incentives, risk aversion, corporate governance, international comparisons

\footnotetext{
- Corresponding author: Martin J. Conyon, The Wharton School, University of Pennsylvania. E-mail conyon@wharton.upenn.edu. We would like to thank Mary Barth, Bill Beaver, Jim Brickley, Peter Cappelli, Alexander Dyck, George Foster, Alan Jagolinzer, Bjorn Jorgenson, Brian Main, Michael Orszag, Graham Sadler, Ross Watts, Joanna Wu, Jerry Zimmerman and seminar participants at Baruch College, the 2005 Royal Economic Society meetings, Imperial College London, Manchester University, the 2005 NBER Summer Institute, New York University, Pennsylvania State University, Rutgers University, Singapore Management University, Stanford University, the University of Pittsburgh, the University of Rochester, and the University of Utah 2006 Winter Conference for comments and suggestions. We thank Sophia Hamm for excellent research assistance. We are especially grateful to Richa Gulati, Michael Orszag, to Watson Wyatt for their help with UK pay data, to Jie Cai and Anand Vijh for sharing their executive equity portfolio valuation software, and to Volkan Muslu for sharing his European CEO compensation and incentives data.
} 


\section{Introduction}

Since at least as early as the 1950s, the press and academic researchers have remarked on the high levels of US CEO pay and questioned whether these levels are consistent with share value maximization [e.g., Murphy (1999)]. As these high levels have continued, there has been an increased willingness among academic researchers to suggest that US CEO pay practices reflect managerial rent-extraction. ${ }^{1}$ The purpose of this paper is to shed light on this issue by comparing CEO pay and incentives in the US with CEO pay and incentives in the UK, the latter being a country with a similar economy, but where excessive pay and managerial rent extraction are generally considered to be less problematic. Specifically, we examine whether, and to what extent, pay differences between US and UK CEOs can be explained by differences in incentives and in risk premiums paid to CEOs for bearing incentive risk. Our results suggest that the commonly-held view that US CEO pay is high relative to UK CEO pay may not hold once one considers the risk premiums attributable to greater holdings of risky equity incentives.

The suitability of corporate governance in general, and of executive compensation and incentives in particular, continues to be of much interest to both academics and practitioners. The spate of corporate scandals in the United States over the last decade, as well as accusations about corporate largesse in the face of the current financial crisis, have once again focused attention on the pay received by those at the very top of organizations. Moreover, a growing body of academic research proposes that problems with US governance and CEO pay are so profound that overpayment of CEOs is not limited to a few bad apples, but that all CEOs in the US economy are overpaid [e.g., Bebchuk and Fried (2004) and Jensen, Murphy, and Wruck (2004)]. If this conjecture is correct, within-country benchmarking can provide an indication of

\footnotetext{
${ }^{1}$ See Core, Holthausen, and Larcker (1999), Bebchuk and Fried (2004), Bebchuk, Fried, and Walker, (2002), Jensen, Murphy, and Wruck (2004).
} 
how compensation practices vary with governance quality within the US, but tells us little about whether US executive compensation practices as a whole suffer from systemic poor governance and excessive pay. Instead it is necessary to compare US practices with those of other countries where compensation practices ex ante are expected to suffer from these problems to a lesser extent [e.g., Core, Guay, and Thomas (2005) and Holmstrom and Kaplan (2003)].

In this paper, we use the United Kingdom as a benchmark against which to examine whether CEO pay in the United States appears unusually high. These two economies share important governance features (such as active takeover markets, unitary board structures, etc.). However, the UK is generally considered to be less afflicted by problems of excessive executive compensation. As we discuss below, and as is detailed in Becht, Franks, Mayer, and Rossi (2006), certain features of the UK governance environment may constrain pay. For example, unlike the US, UK shareholders vote on executive compensation packages. Further, in a comparison of pay between the two countries in 1997, Conyon and Murphy (2000) show that, after controlling for economic determinants of pay, CEO compensation in the UK is systematically lower than in the US.

Using US and UK CEO pay and incentives data for 1997 and 2003, we show that US CEOs have greater pay, but also hold substantially greater equity incentives than their UK counterparts. For example, after controlling for firm characteristics, the US CEOs' 2003 pay was about 1.3 times the pay of UK CEOs. However, US CEOs’ 2003 equity incentives were about 4.6 times greater than those of UK CEOs (the 1997 differences in pay and incentives were even greater).

A central tenet of agency theory and contracting predicts that executives will require greater pay to bear greater incentive risk (e.g., Pratt, 1964). The key research question in our 
paper is whether some or all of the difference in pay between US and UK CEOs can be explained by greater risk premiums paid to US CEOs as compensation for their holdings of greater equity incentives. To examine this hypothesis, we first note that total pay to a risk-averse CEO is the sum of a risk premium for bearing incentive risk plus "risk-adjusted pay," which consists of compensation for CEO ability, compensation for CEO effort, and any rents the CEO obtains. For convenience we term these two components of pay "risk premium" and "risk-adjusted pay." To partition pay into these components, we extend the method used in Cai and Vijh (2005), and estimate risk premiums for US and UK CEOs using data on equity incentives and various assumptions about CEO risk-aversion and outside wealth. We then subtract these risk premiums from total pay to estimate CEOs’ risk-adjusted pay.

For a reasonable range of parameters, we find that after controlling for the risk premium, risk-adjusted pay for the US CEOs is not consistently higher than that for UK CEOs (specifically, we find risk-adjusted pay to be higher for US CEOs in 1997, but higher for UK CEOs in 2003). We conclude that critics of high US executive pay should give greater consideration to the incentives borne by US CEOs and the risk premiums that executives are likely to require to bear these incentives. We also note that while our risk premium estimates undoubtedly contain measurement error, the main takeaway from our analysis seems unlikely to be altered: that risk premiums in CEO pay must be considered to draw accurate inferences about the appropriateness of CEO pay levels. Further, we recognize that although risk premiums offer a potential economic explanation for why US pay is higher than UK pay, it leaves open the question of why US incentives are so much larger than UK incentives. We discuss differences in wealth accumulation as a potential reason for these differences, and suggest that researchers 
should shift their efforts toward better understanding the reasons for differences in incentives between US CEOs and CEOs in other parts of the world.

As a supplemental and exploratory analysis, we also examine pay and incentive differences between a sample of 40 non-UK European (EU) CEOs and a matched sample of US CEOs. Similar to the UK-US analysis, we find that EU CEOs receive less pay and hold less equity incentives that US CEOs. Using estimates of the risk premium to construct measures of risk-adjusted pay, we find that about half of the difference in US-EU CEO pay may be explained by differences in equity incentives. Although these findings provide an interesting perspective on US-EU CEO pay differences, we caveat these results by noting that there are likely to be greater differences in governance, institutional, and social structures between US and non-UK EU firms that between US and UK firms.

In the next section, we motivate the paper, review related literature, and describe our sample and data. In Section 3, we present univariate and multivariate comparisons of pay and incentives for the US and UK over time. In Section 4, we estimate risk premiums related to incentive holdings and examine whether US pay is high compared to UK pay once differences in incentives are controlled for. Section 5 provides exploratory analysis of differences in riskadjusted pay between non-UK European firms and US firms. In the final section, we offer concluding remarks and caveats to our conclusions.

\section{Executive compensation in the US and UK: Motivation and data}

\subsection{Motivation and literature review}

Recent research has suggested that US pay is "too high" and that CEOs are able to exploit existing governance arrangements and extract rents [Bebchuk and Fried (2004) and Bebchuk, 
Fried, and Walker (2002)]. The claim that US CEO pay is "too high" begs the question - "too high compared to what?” If the pay of every CEO within an economy is considered excessive, then there is no within-economy control group against which to evaluate the compensation package of any given CEO. In this paper, we compare US CEO pay to UK CEO pay. The US and UK have very similar economies, but as we describe below, the UK is generally considered to be less afflicted by problems of excessive executive compensation. As such, the UK can be usefully considered as a control group with which to compare US CEO compensation.

The extant research investigating international differences in CEO pay arrangements is sparse. Indeed, the majority of executive compensation papers are single country studies rather than research designed to probe cross-country differences in pay setting strategies. An exception is Conyon and Murphy (2000), who find that after controlling for size, sector and other firm and executive characteristics, US CEOs earned 45\% higher cash compensation and 190\% higher total compensation in 1997 than UK CEOs. ${ }^{2}$

What explains these pay differences? Conyon and Murphy (2000) argue that the differences could be largely attributed to greater stock option awards in the US arising from institutional and cultural acceptance of equity pay in the US vis-à-vis the UK. Consistent with this explanation, Abowd and Kaplan (1999) examine survey pay estimates from Towers Perrin from 1984 to 1996 and find that stock options, expressed as a fraction of CEO pay, were increasing in the US but not elsewhere. Consistent with options contributing to an excessive pay problem, several researchers, such as Hall and Murphy (2002) and Jensen, Murphy and Wruck (2004), argue that US compensation committees historically have under-appreciated the full cost

\footnotetext{
${ }^{2}$ Other research examining international differences in pay and governance includes Crystal, Main, and O’Reilly (1994) and Abowd and Kaplan (1999) for the US relative to the UK, Kaplan (1994a, b) for the US relative to Japan and Germany, and Conyon and Schwalbach (1999) for differences in European pay.
} 
of options, and as a result, overpaid executives with option grants. Further supporting this conjecture, until recently, stock option disclosures were more detailed in the UK than in the US.

A second, and related, explanation is that pay-related governance problems are more severe in the US. By this explanation, US firms overpay their executives using stock options because option pay is less visible to shareholders [e.g., Bebchuk and Fried (2004)]. Although the governance structures of the US and UK are similar in many respects (e.g., both economies have active takeover markets, single board internal control systems with remuneration committees, etc.), differences do exist. For example, the roles of the CEO and Chairman positions are more often separated in the UK. ${ }^{3}$ Further, UK shareholders vote regularly on executive compensation packages, although there is no evidence that say-on-pay proposals change the level or growth of CEO pay (e.g., Ferri and Maber, 2008). The outcome of this voting mechanism is frequently negative, and although the vote is not binding, companies often adhere to them. Also, until very recently UK firms, but not US firms, were required to disclose whether a compensation consultant was hired by management to design their pay packages and the name of the consulting firm. As a final point, if the UK has lower tolerance of income inequality, this would constitute another cultural norm or governance mechanism that constrains executive pay.

A third possibility, which we explore in this paper, is that there is no difference in the efficiency of pay outcomes in the two countries. Instead, differences in pay between the US and UK may be explained by differences in risk premiums for bearing incentive risk. If the optimal contract requires a CEO to hold more incentives, the CEO will demand more pay. Prior research provides some initial support for this conjecture. Conyon and Murphy (2000) find that in 1997 US CEOs held greater equity incentives than did UK CEOs. Conyon and Murphy briefly

\footnotetext{
${ }^{3}$ See, for example, “No excessive pay, we’re British,” The Wall Street Journal, February 8, 2006, page C1.
} 
consider, but dismiss, the equilibrium explanation that US executives have larger incentives and therefore larger pay.

\subsection{Data description}

Our primary goal in this paper is to explore the role of incentive risk in a comparison of US and UK CEO compensation. While the US data are readily available in machine-readable form, the UK data require hand collection. ${ }^{4}$ Because of the costs of hand collection, we limit ourselves to examining the year of the latest available data at the time we began this study, 2003, and the year of the earliest available UK data, 1997 (the basic points of the paper, however, are not expected to be sensitive to particular years chosen for analysis). ${ }^{5}$ Our UK data are handcollected from annual reports and accounts of UK firms (broadly equivalent to US DEF 14A proxy statements). These companies are drawn from the largest 250 UK publicly traded firms ranked by market capitalization in each of the years. We report results based on 177 UK CEOs in 1997 and 214 UK CEOs in 2003 for which we have complete data. As supplemental analysis, in Section 5, we also explore the role of incentive risk in a comparison of US CEO pay with CEO pay of firms in other non-UK European countries.

Our US data come from the comprehensive Compustat ExecuComp database, which includes firms in the S\&P 500, the S\&P MidCap 400, the S\&P SmallCap 600, and the S\&P supplemental indices. Our US sample consists of 1,372 CEOs in 1997 and 1,511 CEOs in 2003.

\footnotetext{
${ }^{4}$ Unfortunately, it is both labor- and time-intensive to collect UK executive compensation data. Although compensation disclosure in the UK was significantly expanded following the Greenbury (1995) and Hampel (1998) reports, the disclosed data is usually not available electronically and must be hand-collected. Moreover, the information is not reported in the same tabular form across different companies, making data collection more difficult. Currently, UK companies disclose information comparable to those available for US executives including exercise prices, maturity terms, options granted and information on stock options outstanding.

${ }^{5} 1997$ is the first year that UK companies were required to disclose data on stock option grants to top executives. For a similar reason, prior studies of US pay often begin at 1992 because this is the first year that US companies were required to disclose data on stock option grants to top executives.
} 
However, as shown in Panels A and B of Table 1, because we examine the largest 250 UK firms, the median US firm tends to be smaller than the median UK firm. The median UK firm has sales of $\$ 1.6$ billion ( $\$ 1.8$ billion) in 2003 (1997), as compared to median sales for the US firms of \$1.1 billion (\$1.0 billion) in 2003 (1997). Similar size differences are observed between the UK and US firms based on market capitalization. To mitigate the concern that our findings are influenced by size differences across the US-UK firms, in most of our tests, we focus on a subsample of US firms that are matched (within industry) to the UK firms using a propensityscore procedure (discussed in more detail below). ${ }^{6}$

\subsection{Measurement of CEO pay and incentives}

Executive compensation in the UK and the US consists of the same basic elements. CEOs in both countries receive base salaries and are eligible to receive annual bonuses, usually based on accounting performance. CEOs in both countries frequently receive stock options, and can also receive restricted stock. In the US, restricted stock grants typically vest with the passage of time but not with performance criteria. In the UK, by contrast, the vesting of restricted stock is typically tied to the attainment of performance objectives. In our empirical work, we define total pay for the firm's CEO as the sum of salary, bonus, benefits, stock options, restricted stock grants (valued at $100 \%$ of performance contingent awards) and other compensation. ${ }^{7}$ We estimate the grant date value of options granted during the year using a modified version of the Black-Scholes (1973) model. Consistent with the findings of Hemmer, Matsunaga and Shevlin (1996) and Huddart and Lang (1996) that employees exercise options prior to maturity, we

\footnotetext{
${ }^{6}$ All of our inference holds when we conduct our tests using the full US sample.

${ }^{7}$ In the case of the United States, we use variable item TDC1 from the ExecuComp database. For the UK we calculate total pay from information contained in the annual reports.
} 
assume the expected time-to-exercise is $70 \%$ of the option grant's stated maturity. Our inference, however, is unaffected if we value the option grant using the stated time-to-maturity.

Panel C of Table 1 provides descriptive statistics for CEO total pay for our full sample of US and UK firms. We provide figures for the average and median values, as well as the percentage change in these values from 1997 to 2003. The total pay data illustrate that the broad sample of US CEOs earn more than the sample of British CEOs. In 1997, the median US CEO's pay was $\$ 2.0$ million, or $100 \%$ more than the median UK CEO’s pay of \$1.0 million. In 2003, the median US CEO’s pay was $\$ 2.5$ million, or 30\% more than the median UK CEO’s pay of \$1.9 million. Note that the higher pay for US CEOs is observed in spite of the fact that the US firms in the full sample are somewhat smaller than the UK firms (we control for this size difference explicitly below). As a final point on Panel C, the pay differential between the US and UK CEOs appears to have narrowed between 1997 and 2003. ${ }^{8}$ There is a 92\% increase in median UK CEO pay from 1997 to 2003, as compared to a 29\% increase in median US CEO pay over this time period. ${ }^{9}$

We turn now to our measure of CEO equity incentives, which recognizes that incentives are greater when the CEO has more of his wealth invested in firm equity and less in other assets. The sensitivity of annual pay to stock returns captures only a small part of CEO equity incentives. Much greater incentives are provided by the sensitivity of the CEO's holding of

\footnotetext{
${ }^{8}$ Although the determinants of changes in pay and incentives for UK CEOs over time is an interesting research question, the objective of our study is to explore the implications of equity incentive risk premiums for crosssectional differences in US vs. UK (and EU) CEO pay. That is, we seek to understand whether US and UK pay appears to be different once pay is adjusted for the risk premium stemming from equity incentives.

${ }_{9}^{9}$ As a caveat to interpreting the changes in pay over time, we note that changes in business conditions over the sixyear window from 1997 to 2003 have not been identical in the US and UK. For example, in Panel B of Table 1, we show that the median US firm's market value fell by 2\% from 1997 to 2003 compared to a decline of $27 \%$ for the UK sample firms. This relatively greater decline in market values for UK firms makes the relatively greater increase in UK pay even more surprising. Aggregate price inflation from 1997 to 2003 was $8.1 \%$ in the UK (1.3\% per year) as compared to $15.2 \%$ in the US (2.4\% per year), but these changes in general price levels seem unlikely to explain the observed pay changes. We also note that average exchange rates were very similar in 1997 and 2003: in both years, one UK pound sterling was worth about 1.64 US dollars.
} 
stock and options to changes in shareholder value. Stock and options directly link CEO wealth to shareholder value, and are the major component of total CEO equity incentives [Hall and Liebman (1998) and Jensen and Murphy (1990)].

We measure equity incentives as equivalent stock value. For example, we refer to $\$ 100$ of stock as having $\$ 100$ of incentives. However, because options are equivalent to a leveraged investment in stock, $\$ 100$ of options has a greater sensitivity to stock returns, and greater incentives, than $\$ 100$ of stock. To estimate the sensitivity of option value to stock price, i.e., the option portfolio delta, we use the method developed by Core and Guay (2002), with option maturities set to $70 \%$ of the Core and Guay assumed times-to-maturity to adjust for expected early exercise. We compute the total incentive measure as: (share price) $\times$ (the number of shares held $)+($ share price $) \times($ option delta $) \times($ the number of options held $) .{ }^{10}$ We note that our incentive measure is a scaled version (i.e., multiplied by 100) of a commonly-used incentive measure: dollar change in the CEO's wealth from a 1\% stock price increase [Baker and Hall (2004) and Core and Guay (1999)]. We use the scaled equivalent stock value incentive measure to facilitate our later discussions of the risk premium required for holding incentives.

In Panel D of Table 1, we provide descriptive evidence that US CEO equity incentives are greater than those of UK CEOs. The median US CEO in 2003 had incentives equal to about $\$ 19.6$ million in stock equivalent value. That is, for each $1 \%$ increase in the stock price, the median CEO would experience a $\$ 196,000$ increase in his equity value (=1\% x $\$ 19.6$ million). This compares to the median UK CEO incentives of about \$3.8 million in stock equivalent value. The incentive data are positively skewed with mean values substantially greater than median values. This skewness is largely due to a small percentage of both US and UK CEOs who hold very large amounts of equity. Between 1997 and 2003, the median UK CEO incentives increased

\footnotetext{
${ }^{10}$ Shares held includes restricted stock and performance-vested restricted stock.
} 
by about $58 \%$ compared to $24 \%$ for US CEOs' incentives. Overall, the evidence in the bottom two panels of Table 1 shows that American CEOs have greater wealth and incentives in their firms compared with their British counterparts, but that UK CEOs' incentives have exhibited a greater relative increase from 1997 and 2003.

\section{Analysis of relative US and UK CEO pay and incentives}

We begin our analysis by showing that the US-UK pay difference, which has previously been documented in the literature, holds within our data. Although the descriptive statistics in Table 1 suggest such a premium, a proper test should control for differences in firm characteristics known to vary with CEO pay.

Columns (1) and (2) of Table 2 report coefficient estimates of the US-UK pay difference, using OLS regression methods and controlling for company size, growth opportunities, firm performance, stock idiosyncratic risk, leverage, and industry factors. Extant research on executive compensation has consistently hypothesized and found that larger firms with greater growth opportunities require more talented and more highly paid managers [e.g., Smith and Watts (1992)]. In addition, researchers often include controls for company performance, tenure, and firm risk (as proxies for ability or demand for ability). The models therefore include as controls the market value of the firm dated at $\mathrm{t}-1$, the book-to-market assets ratio dated at $\mathrm{t}-1$, the performance of the firm (measured as the one-year total return to shareholders), the idiosyncratic risk of shareholder returns (as a proxy for risk), CEO tenure, and a set of industry dummy variables. We also include a proxy for leverage, measured as the ratio of book value of liabilities to market value of assets. Prior research finds that annual pay is greater for CEOs that also serve as Chairman of the Board, and UK CEOs are typically less likely than US CEOs to serve both of 
these roles (see also Columns 5 and 6 of Table 2, which indicate that UK CEOs are less likely to serve as the Chairman in our sample). We therefore include a CEO-Chair Indicator variable taking the value of 1 if the CEO is also board chair, and zero otherwise. The dependent variable in columns (1) and (2) is $\log ($ Total Pay). Regressions including both US and UK CEOs are performed separately for 1997 and 2003 in columns (1) and (2).

Consistent with prior research, Table 2 indicates that CEO pay increases with firm size, growth opportunities, risk, and performance. However, the main coefficient of interest in columns (1) and (2) is the variable "US indicator" which is equal to one if the firm is US and zero if UK. The coefficient estimate on the US indicator variable for 2003 in column (2) is a significantly positive 0.25 , indicating that after controlling for various firm, CEO, and industry factors, CEOs in the US earn approximately 28\% more total compensation than their British counterparts in that year. An interesting feature of Table 2 is that it shows a narrowing of pay differences from 1997 to 2003. US CEO total pay was about 92\% higher than UK CEO pay in 1997, but this difference narrowed to $28 \%$ in $2003 .^{11}$

Columns (3) and (4) of Table 2 report coefficient estimates of the difference between US and UK incentives using a series of OLS regressions similar to those for total pay in columns (1) and (2), and controlling for company size, growth opportunities, idiosyncratic risk, CEO tenure, a CEO-Chair indicator, and industry factors. The dependent variable in all columns is log(equity

\footnotetext{
${ }^{11}$ We note that relatively little of these differences in pay is likely to be explained by differences in personal taxes or cost of living across the two countries. The top marginal tax rates are similar for the US and UK, and stock option grants and exercises are taxed similarly. Executives in the US are typically taxed at the highest marginal tax rate, which is currently about $39 \%$, but the full US tax rate is somewhat higher, due to state and local taxes ranging from $0 \%$ to about $10 \%$, depending on the jurisdiction. In the UK, the highest marginal tax rate is $40 \%$ (although this top rate is applicable at lower income levels in the UK). Further, the cost of living in major metropolitan areas is roughly similar across the two countries. Mercer Human Resource Consulting (2005) conducts a Cost of Living Survey which covers 144 cities across six continents and measures the comparative cost of over 200 items in each location, including housing, transport, food, clothing, household goods and entertainment. London is the most expensive city in Europe and is ranked third globally, while New York is the most expensive city in the US and is ranked thirteenth globally. Outside of major metropolitan areas, the cost of living in the UK is generally lower than that of comparable US cities.
} 
incentives). As in Table 2, regressions including both US and UK CEOs are performed separately for 1997 and 2003. The coefficients on the control variables in the incentives regressions are consistent with prior literature: Larger firms with greater growth opportunities use more incentives, and CEOs with longer tenure and who also serve as board chair hold more equity incentives. Consistent with prior mixed results on the association between risk and incentives, idiosyncratic risk shows a positive association with incentives in column (3), and a negative association in column (4).

In the 2003 regression, the coefficient estimate on the US indicator is 1.72 and indicates that, after controlling for firm, CEO, and industry factors, CEOs in the US hold about 464\% more equity incentives than their UK counterparts in that year. This suggests that CEOs in the US have much more wealth tied up in firm equity that is at risk to adverse price shocks. ${ }^{12}$ As with the pay difference, the US-UK incentive difference in 2003 has declined somewhat from 1997 (464\% vs. 582\%, respectively).

The regressions in columns (1)-(4) indicate, not surprisingly, that CEO pay and incentives are influenced by many firm characteristics, such as size and growth. Further, the descriptive statistics in Table 1 indicate that the US and UK samples differ across some of these dimensions. Therefore, to facilitate clear comparisons across the two samples, we use a propensity-score-matching procedure to select a firm from the US sample (which contains a much larger number of observations) for each UK firm. The propensity scores are computed based on the by-year logit regressions presented in columns (5) and (6) of Table 2, which include all the control variables from columns (1)-(4). The dependent variable is a "UK indicator" which is equal to one if the firm is UK and zero if US. The significant positive coefficients on tenure in

\footnotetext{
${ }^{12}$ We note that differences in incentives borne through risk of CEO turnover are unlikely to account for these differences in incentives. Average UK CEO turnover is similar to, if not somewhat less frequent than, that of the US [e.g., Conyon and Murphy (2000) and Dahya, McConnell, and Travlos (2002)].
} 
both years suggest that UK CEOs serve longer, and the negative coefficient on board chair suggests that fewer UK CEOs are also board chairs. Finally, UK firms tend to be less risky and to have lower shareholder returns. We match each UK firm to the US firm with the closest propensity score within two-digit SIC code (the propensity-score regressions only include US observations for which there is a UK observation in the same industry).

Table 3 presents descriptive statistics for the propensity-score-matched US sample. As expected and by construction, there are much smaller differences in firm size (sales and market value) between the two samples. Most importantly for our purposes, however, the direction and magnitude of differences in total pay and incentives are quite similar to the descriptive statistics presented in Table 1. For the remainder of the paper, we focus on the propensity-score-matched US sample in our analyses.

\section{Results - The relation between pay and incentives}

To this point, we have illustrated that the level of CEO compensation is higher for American CEOs compared to British CEOs. Further, we show that US CEOs have more wealth at risk in their companies' stock and stock options relative to UK CEOs. There are economic benefits and costs to imposing incentives. The benefits of incentives are that they align the CEO's interests with those of shareholders and encourage the CEO to make decisions that increase shareholder value. However, the cost of these incentives is that a CEO will not work unless he is adequately compensated, and a risk-averse CEO will demand more compensation as the amount of incentives imposed is increased. All agency models predict that the greater the amount of incentives imposed on an agent, the more he will be paid. Recent research emphasizes that risk-averse and undiversified CEOs discount the value of their firm-specific equity [e.g., 
Hall and Murphy (2002)]. This occurs because CEOs would prefer to invest their wealth in a more diversified portfolio, and therefore do not value $\$ 1$ in firm stock as much as \$1 invested in this more diversified portfolio. The more incentives the CEO holds, the less his wealth is diversified, and the greater the risk premium he requires.

The idea that pay will be higher when incentives are higher can also shed light on the differences between CEO pay in the US and the UK. Table 4 provides a descriptive example. Columns (1) and (2) show median CEO total pay and beginning-of-year CEO portfolio incentives for 1997 and 2003, respectively. Recall that this incentive measure is defined as the change in the value of CEO equity holdings for a percentage change in the stock price, and equates $\$ 100$ in stock to $\$ 100$ in incentives. Column (3) shows that in 1997 (2003) the median US CEO received $\$ 1,163,000(\$ 442,000)$ more pay and held $\$ 12,783,000(\$ 14,587,000)$ more incentives. In the final row of each panel, we compute the ratio of incremental pay received by the median US CEO for incremental incentives held. This incremental pay is $9.10 \%$ per unit of incentives in 1997, and 3.03\% per unit of incentives in 2003. In other words, our matched sample of US CEOs receive between $\$ 3.03$ and $\$ 9.10$ in extra annual pay for holding an undiversified position equivalent to $\$ 100$ in firm stock. In the next section, we explore whether the magnitude of this premium appears reasonable given various assumptions about CEO risk aversion, wealth, firm characteristics.

\subsection{Estimating the risk premium for holding incentives}

That CEOs who hold greater incentives should receive greater pay seems reasonable. The key question is what magnitude of extra pay would we expect the US CEOs to receive given the extra incentives they hold? In other words, is a range of $\$ 3.03$ to $\$ 9.10$ in extra pay per $\$ 100$ of 
extra incentives reasonable? Some light can be shed by extending the work of Hall and Murphy (2002) and Cai and Vijh (2005) on the risk premium a CEO will require for accepting equity pay in lieu of cash pay. Hall and Murphy and Cai and Vijh show that the magnitude of the risk premium increases with the proportion of the manager's wealth that is invested in firm equity (as opposed to diversified assets) and with the CEO's risk-aversion. Both outside wealth (money not held in firm equity) and risk-aversion are unobservable to the researcher. However, prior literature typically assumes that outside wealth ranges between $50 \%$ and $100 \%$ of the CEO's inside wealth. For example, if the CEO owns $\$ 10$ million in firm equity, the literature assumes that his outside diversified holdings range from $\$ 5$ million to $\$ 10$ million. In addition, the literature typically assumes that the CEO's relative risk-aversion ranges from two to three [see for example, Hall and Murphy (2002) and Cai and Vijh (2005)].

Part of pay can be thought of as compensation for the CEO holding firm equity instead of selling the equity and diversifying (holding aside the component of pay related to the CEO's skill and cost of effort, and any rents that he may extract, which we refer to as "risk-adjusted pay"). In other words, one can think of a portion of annual pay as the risk premium paid to the CEO for holding an undiversified position in firm equity for the next year. Another way to think of this risk premium is: How much less pay would the CEO accept if he were released from the restriction that he hold a substantial fraction of his wealth in firm stock? To estimate this risk premium, we extend and modify the methods of Hall and Murphy (2002) and Cai and Vijh (2005). We solve for the risk premium the CEO requires to be indifferent between (1) receiving the risk premium and holding the firm equity position for one year, and (2) not receiving the risk premium, selling his firm equity, and holding a diversified portfolio instead.

We derive the risk premium by numerically solving the following equation: 


$$
\begin{aligned}
& E[U(\text { wealth unconstrained })]= \\
& E[U(\text { wealth constrained to firm equity, outside wealth, risk premium })]
\end{aligned}
$$

Wealth constrained to firm equity (inside wealth) is the CEO's beginning-of-year portfolio of stock and options. We assume: (1) the CEO's outside wealth is either $50 \%$ or $100 \%$ of the CEO's inside wealth, (2) the CEO has a power utility with relative risk-aversion of either 2 or 3, and (3) the CEO may invest his outside wealth in long positions in both the market portfolio and the risk-free asset (but may not sell short). ${ }^{13}$ The expression on the left side is the utility the CEO would receive if he could invest his total wealth in a utility-maximizing combination of the riskfree asset and the market portfolio. We assume that this unconstrained wealth is equal to the market value of the CEO's stock and options, plus his outside wealth. ${ }^{14}$ The expression on the right side is the utility the CEO receives when he is constrained to hold the assumed fraction of his wealth in firm stock and options for one year, but may sell the securities at market value at the end of the year. We assume that the CEO invests the remainder of his wealth in a utilitymaximizing combination of the risk-free asset and the market portfolio, and that he holds these positions for one year. We assume a one-year holding period to match the period over which annual compensation is paid. ${ }^{15}$ The risk premium is the dollar amount that sets the two sides equal, and is assumed to be paid by the firm to the CEO at the end of the year.

\footnotetext{
${ }^{13}$ Our assumption that the CEO chooses between the market portfolio and the risk-free asset is consistent with the literature, but is an abstraction of people's real-world portfolio choices that may include large investments in other assets such as homes and other real estate. To the extent that portfolio choice varies by country, it may indicate differences in risk-aversion or in proportions of outside wealth across the countries. We discuss in sensitivity analysis in Section 4.3 below how our inference would vary if UK CEOs differed from US CEOs in risk-aversion or in proportions of outside wealth.

${ }^{14}$ To the extent that the CEO owns options or restricted stock, he will not be able to invest the market value of firm equity in a diversified portfolio. However, the objective of our method is to make comparisons of CEOs with different types of firm equity by asking the question: How much less pay would the CEO accept if he were released from the explicit or implicit restriction that he hold a portion of his wealth in firm stock?

${ }^{15}$ Clearly some forms of compensation are restricted for multiple years, and options (if the executive wishes to obtain their full value) are implicitly restricted for the entire maturity. On the other hand, CEOs typically also own unrestricted stock and fully vested options. However, as noted above, the objective of our method is to make comparisons of CEOs with different types of firm equity by asking the question: How much less pay would the
} 
As an illustration of this method, in Table 5, we show the estimated risk premium for holding incentives for a hypothetical CEO. For convenience, we express this risk premium as a percentage of the CEO's incentives. ${ }^{16}$ Consistent with intuition, the table shows that the CEO requires a greater risk premium when he is more risk-averse and when more of his wealth is concentrated in firm stock. For our hypothetical CEO, when relative risk-aversion is two (three) and $50 \%$ of his wealth is in firm stock, he requires a risk premium of $5.8 \%(8.5 \%)$. If the CEO is less diversified and holds $67 \%$ of his wealth in firm stock, he requires a risk premium of $7.6 \%$ (11.0\%) for a risk-aversion parameter of two (three). An estimated risk premium of $7.6 \%$ means that if the CEO has incentives of $\$ 1,000,000$, he will require an annual risk premium of $\$ 76,000$ to compensate him for his lack of diversification. Another way to consider the risk premium is to suppose that a completely diversified shareholder requires a return of $10.0 \%$ on the firm's stock. Then the CEO, because he is undiversified, requires a return of $17.6 \%, 7.6 \%$ in extra annual pay on top of the $10 \%$ expected return. The estimated risk premiums in Table 5 appear comparable to the incremental US pay per unit of incentives shown in Table 4. In 2003, the median US CEO received \$442,000 more pay for holding about \$14.6 million more incentives, or an incrementalpay-to-incremental-incentive ratio of $3.03 \%$ (in 1997, the incremental-pay-to-incremental incentive ratio was $9.10 \%$ ). This $3.03 \%$ to $9.10 \%$ range of incremental-pay-to-incremental incentive ratios is slightly lower than, but roughly consistent with, the range of $5.8 \%$ to $11.0 \%$ shown in Table 5.

CEO accept if he were released from the explicit or implicit restriction that he hold a portion of his wealth in firm stock?

${ }^{16}$ Under our assumption that the CEO has constant relative risk-aversion, the risk premium will be proportional to the magnitude of the incentives. For example, if the CEO's inside and outside wealth both increase by a factor of 10 , the risk premium will also increase by a factor of 10 . This makes it convenient to scale the computed risk premium, and in the table, we express the risk premium as a percentage of incentives. 
It is important to note that we estimate a different risk premium than do Hall and Murphy (2002) and Cai and Vijh (2005), although we use similar numerical methods to Cai and Vijh. This prior work focuses on determining the executive's value of a new option grant by solving the following equation:

$E[U$ (wealth constrained to firm equity, outside wealth,option) $]=$ $E[U$ (wealth constrained to firm equity, outside wealth, executive's value) $]$

The difference between the market value of the option (left-hand-side) and the executive's value (right-hand-side) is the risk premium associated with the option. Because of its interest in determining the executive's value for a new option grant, this work holds constant the risk premium for holding the existing portfolio, and solves for the incremental risk premium for a new option grant. In contrast, we solve for the risk premium associated with holding the entire existing equity portfolio.

\subsection{Estimating risk-adjusted pay}

As described above, we conceive of total pay as compensation for ability and effort, plus a risk premium. Given an executive's incentives, one can estimate the risk premium and subtract it from total pay to obtain an estimate of "risk-adjusted pay". For example, if one were to assume that CEOs in both the US and UK have relative risk-aversion of two and have $50 \%$ of their wealth in firm stock, our analysis suggests that the CEOs would receive a risk premium of 5.8\% for bearing their incentive risk. In Table 6, we use the median data shown in Table 4 to obtain an estimate of the median risk-adjusted pay received by these CEOs. We compute the median riskadjusted pay by subtracting 5.8 times the CEO's beginning-of-year incentives from his total pay (5.8\% is approximately the midpoint of the observed incremental pay per unit of incentives 
reported in Table 4 for 1997 and 2003, and is the smallest of the estimated risk premium percentages presented in Table 5).

The analysis in Table 6 suggests that controlling for the risk premium substantially reduces the pay differences between US CEOs and UK CEOs. In 1997, the median matched US CEO received $118 \%$ more pay than the median UK CEO and held about 531\% more equity incentives. After deducting the risk premium compensation for holding the median level of incentives, the median risk-adjusted pay in 1997 is 50\% greater for US CEOs than UK CEOS (\$1,267,000 vs. $\$ 845,000)$. In 2003, we observe an even more striking result. The median matched US CEO received 23\% more pay in 2003 than the median UK CEO and held 383\% more equity incentives. After deducting the US and UK CEOs' expected compensation for holding incentives, the median risk-adjusted pay in 2003 is 32\% greater in the UK $(\$ 1,266,000$ for the median US CEO vs. $\$ 1,670,000$ for the median UK CEO). ${ }^{17}$

In Table 7, we examine whether these median results hold when the risk premium adjustment is applied on a CEO by CEO basis (as opposed to simply illustrating results using the median CEO). To compute a risk premium for each CEO, we use Equation (1) above with an assumption that CEOs have relative risk-aversion of 2 and $50 \%$ of their wealth outside the firm. Inputs into the calculation are each CEO's beginning-of-year stock and option portfolio, the firm's beta and volatility, an assumed market volatility of $20 \%$, a risk-free rate of $5 \%$, and a market risk premium of 6\%. We then compute each CEO’s risk-adjusted pay by subtracting the computed risk premium from his total pay. In Panel A, we present the computed risk premiums

\footnotetext{
${ }^{17}$ The UK, to a much greater extent than the US, makes the vesting of options (and restricted stock) contingent upon the achievement of performance targets (e.g., Main, 2005). To the extent that these targets are non-trivial, performance-based vesting will lower the value of an option or restricted share and decrease the incentives provided by the equity (e.g., Johnson and Tian, 2000). We do not have data to feasibly incorporate these effects into our analysis. As a result, our calculated numbers may somewhat overstate UK pay, and also overstate UK incentives and the risk premium associated with these incentives. However, because the overstatement of pay will tend to be offset by the overstatement of the risk premium, it is not clear whether our measure of risk-adjusted pay for UK CEOs is somewhat overstated or understated.
} 
as a percentage of incentives, which range from $3.68 \%$ to $7.21 \%$ at the median, depending on the year and country. The greater risk premiums in 2003 are the result of higher estimates of stock return volatility for the US and UK firms in that year. Because our propensity-score-matching procedure matches on idiosyncratic risk, the beta and stock volatility of the matched firms tend to be similar, and as a consequence there is no difference in risk premiums between the US and UK firms.

Panel B of Table 7 shows that the average risk-adjusted pay is $\$ 1,406,000$ for the matched US CEOs in 1997 and $-\$ 11,561,000$ for 2003 , as compared to $\$ 1,008,000$ for the UK CEOs in 1997 and \$936,000 in 2003. The large negative average value for US CEOs in 2003 is due to a small number of US CEOs that hold very large amounts of equity. Setting negative values of risk-adjusted pay to zero (see Column (2)), the adjusted averages show mean US riskadjusted pay that is larger than risk-adjusted pay in the UK (\$2,595,000 vs. \$1,087,000 in 1997 and $\$ 2,651,000$ vs. $\$ 2,086,000$ in 2003).

However, because the averages in both samples are influenced by some extreme observations, as above, we interpret the median values as being more representative of the samples. The median risk-adjusted pay for the US CEOs is about $63 \%$ greater than for the UK CEOs in 1997, $\$ 1,316,000$ vs. $\$ 808,000$, respectively. The median paired difference is significantly greater than 0. From 1997 to 2003, risk-adjusted pay for the UK CEOs increased, largely due to growth in CEO pay over that period. At the same time, US CEO risk-adjusted pay declined from 1997 to 2003, largely due to an increase in the estimated risk premium per unit of incentives (see Panel A of Table 7). As a result, the 2003 ordering of risk-adjusted pay is reversed, with the median UK CEO receiving more risk-adjusted pay than the median US CEO, $\$ 1,564,000$ vs. $\$ 885,000$, respectively. Now, the median paired difference is significantly less 
than 0. Abstracting away from the magnitude, in 1997, 58.2\% of US CEOs had greater riskadjusted pay, but this figure drops to 39.3\% in 2003. Overall, the results in Table 7 (and in Table 6) suggest that the commonly-held view that US CEO pay is high relative to UK CEO pay may not hold once one considers the risk premium attributable to greater holdings of risky equity incentives.

\subsection{Sensitivity Analysis and Interpretation}

We interpret our findings as being consistent with US and UK CEOs receiving similar risk-adjusted pay, or at least that neither country's CEOs appear to receive consistently higher risk-adjusted pay. However, given perceptions by many that US CEOs are overpaid relative to UK CEOs, we now consider a set of necessary conditions for our results to alternatively be interpreted as US CEOs receiving greater risk-adjusted pay relative to UK CEOs. Not surprisingly, such a conclusion requires that either our analysis excludes an important determinant of differences in US-UK pay levels, or that our risk premium estimates or the assumptions we use to develop them are incorrect.

As sensitivity analyses, we first consider the possibility that differences in pay and/or incentives between UK and US CEOs might arise because of US-UK differences in global competitiveness or exchange listing. A more global UK firm is expected to participate in a more global CEO labor market, have a more global shareholder base, and may be more likely pay its CEO (and provide incentives) at levels comparable to those of CEOs in other countries, such as the US. As a proxy for the degree of exposure the UK firm has to global markets and shareholders (and in particular, US shareholders), we construct an indicator variable for whether the UK firm is listed on a US exchange. We also consider that the degree of product market 
competition could potentially influence observed differences in pay between US-UK CEOs. If the higher observed compensation for US CEOs reflects excessive pay, we expect the ability of US firms to excessively pay their CEOs would be reduced in very competitive industries (likewise, CEO incentives in competitive industries should converge). A similar result (i.e., the convergence of pay) is expected if the lower pay in the UK is the result of social norms. As an inverse measure of the degree of market competition, we use the Hirschman-Herfindahl Index of industry product market concentration, calculated using Compustat Global as the sum of squared market shares. Market shares are based on firm sales as a fraction of worldwide industry sales, where industry is based on 2-digit SIC codes. This measure is often used as a proxy of market power in the industrial organization literature since higher values are associated with oligopoly, and in the limit monopoly, power.

In Table 8, we present regression models of the difference in UK-US CEO pay, incentives, and risk adjusted pay. The dependent variable is the difference between each matched pair (from the propensity-score match). The regressions include the Foreign Listing indicator and Hirschman-Herfindahl Index as explanatory variables. The Foreign Listing variable indicates that the pay difference between US and UK CEOs (Column 1) is smaller when UK firms have US exchange listings. Interestingly, the differences in US-UK incentive levels (Column 2) appear to be somewhat greater when UK firms have US exchange listings. This could occur if the US listing improves monitoring, which lowers the need for incentives for the UK firm. Product market competition, as measured by the Hirschman-Herfindahl index does not appear to have explanatory power for differences US-UK pay or incentives. Column (3) shows that the inclusion of the exchange listing and competition do not change our earlier finding that US riskadjusted pay is higher in 1997 and lower in 2003. 
We turn now to consider how differences in the assumptions would change our assessment of US-UK CEO pay differences. We make the implicit assumption that the cost of CEO effort, and the compensation for CEO effort is the same for each pair of CEOs. Edmans, Gabaix, and Landier (2009) use an alternative assumption that is common in macroeconomic models: the cost of effort is proportional to wealth. Intuitively, the wealthier persons have greater opportunity costs. If this assumption is correct, since US CEOs tend to be wealthier, the differences in risk-adjusted pay shown in Table 7 overstate true pay differences: higher pay for US CEOs in 1997 is less positive, and higher pay for US CEOs in 2003 is more negative.

Now suppose that CEOs in both countries had much lower risk-aversion than is assumed in the literature. In this case, the risk premium shown in Panel A of Table 7 would drop substantially for both countries, and US pay would again appear high compared to UK pay. In the extreme, if CEOs were risk neutral and required no risk premium for holding incentives, the comparison of risk-adjusted pay across the two countries would become identical to the comparison shown in Table 3 in which US CEOs receive 118\% (23\%) more pay than their UK counterparts in 1997 (2003).

On the other hand, assuming that the literature's assumptions of relative risk-aversion between two and three are correct, a claim that US CEOs are overpaid relative to UK CEOs would require some combination of the following: (1) UK CEOs hold a greater proportion of their total wealth in firm incentives, (2) UK CEOs are more risk-averse, or (3) the market for skill/ability in the UK is substantially more competitive than in the US.

Although we are unable to provide additional evidence either for or against point (3) above, we are able to provide sensitivity tests for points (1) and (2). To explore how our results would change under the assumptions that UK CEOs are more risk-averse and hold more of their 
wealth in firm incentives, Table 9 revises the analysis in Table 6 to show the effect of assuming that the median UK CEO is more risk-averse (relative risk-aversion of three) than the median US CEO (relative risk-aversion of two), and has more incentives as a percentage of his wealth (67\%) than the median US CEO (50\%). The UK CEO would thus a require a risk premium of $11.0 \%$ of incentives held, as compared to the US CEO, who would require a risk premium of $5.8 \%$ for of incentives held. This analysis shows that the median US CEO received $76 \%$ more risk-adjusted pay than his median UK counterpart in 1997. However, by 2003 this difference had again reversed, with UK CEO risk-adjusted pay being about 16\% greater than US risk-adjusted pay.

In reality, it seems unlikely that UK CEOs hold a greater fraction of their wealth in the firm than US CEOs. If this were true, it would suggest implausibly large wealth differences between the two countries' CEOs. As shown in Table 9, because the median US CEO in 1997 held 6.3 times the incentives of the median UK CEO, an assumption that the US CEO held 50\% of his wealth in the firm compared to $67 \%$ for the UK CEO, would imply that the US CEO had 8.5 times the wealth of the median UK CEO (assuming for simplicity that all of the incentives were held in stock, for which $\$ 100$ in stock $=\$ 100$ in incentives). These very large wealth differences seem less plausible than an assumption of more similar wealth levels between the two countries, with the observed incentive differences caused by US CEOs holding a greater portion of their wealth in the firm. For example, suppose that US CEOs had twice the wealth of their UK counterparts. Then if in 1997 the median US CEO held 50\% of his wealth in the firm while the median UK CEO only held 16\%, this would explain the observed incentive differences in 1997. Note that if it is the case that US CEOs hold more wealth in the firm, our risk premium estimates for UK CEOs will be upwardly biased, suggesting greater risk-adjusted pay for UK CEOs than our Table 6 and 7 estimates. 
A final objection to our analysis might be as follows: Does not the apparently much greater wealth of US CEOs constitute prima facie evidence that they are overpaid? If US CEOs are not overpaid relative to UK CEOs, how do they have so much more wealth? Although an investigation of this issue is beyond the scope of this paper, we note a few potential explanations for why US CEOs might be wealthier than UK CEOs. First, CEOs accumulate wealth through both risk-adjusted pay and through pay for risk. To the extent that US CEOs bear more incentive risk throughout their careers, they will be paid more and accumulate greater wealth (albeit with greater variance), all else being equal. Second, compared to UK executives, US executive income is likely taxed at lower average rates over the individual's career. Although the top marginal tax rate is similar across the US and UK, the top marginal tax rate is applicable at lower income levels in the UK than in the US. The top UK income tax rate of $40 \%$ affects incomes above approximately $\$ 58,000$, whereas the top US income tax rate of $39 \%$ affects incomes above approximately $\$ 300,000$. Thus, future executives in the UK pay greater taxes earlier in their careers and are expected to accumulate less wealth. Further, capital gains of US executives are likely taxed at lower average rates. The capital gains tax rate on gains from equity sales is the same as the income tax rate in the UK. In the US, the top capital gains tax rate has generally been lower than the top marginal tax rate. In comparison to low US capital gains tax rates of $20 \%$ or below throughout our sample period, the UK capital gains rate has been $40 \%$. Finally, we note that retirement ages are not mandatory in the UK. The normal retirement age in the UK is 65, which is similar to the US. Overall, it seems conceivable that US executives are wealthier because they receive higher risk premiums throughout their careers and are taxed at lower income and capital gains rates. 
An alternative argument for why US CEOs appear to accumulate more wealth is that US CEOs are systematically overpaid relative to UK CEOs due to systemic corporate governance weaknesses at US firms relative to UK firms. However, while it is obvious how excess pay leads to greater wealth, it is more difficult to see how this leads to greater incentives. In particular, why would a CEO who has considerable influence over the magnitude of his excess pay choose to bear excessive risk in the form of firm equity? The majority of stock and options held by US CEOs is vested and saleable, and it is difficult to see why CEOs with sufficient clout to ensure excessive pay would not also have the flexibility to liquidate their vested stock and option holdings for the purposes of holding a better-diversified portfolio of assets.

\section{Analysis of US vs. other European CEO pay and incentives}

In this section, we analyze CEO pay and incentives at other non-UK European firms (EU firms). Although we believe this analysis provides some interesting additional insights on the potential importance of the risk premium in US vs. EU CEO pay, we recognize that this comparison gives rise to a substantially longer list of caveats and concerns. Specifically, unlike the US-UK comparisons, there are significant differences in corporate governance systems and practices between continental EU firms and the US (e.g., Becht, et al., 2002). For example, as compared to the US-UK, EU, capital markets tend to be smaller and less liquid, and there is a significantly weaker market for corporate control (e.g., takeovers are relatively infrequent). Ownership of EU firms tends to be more concentrated, and dominant family shareholdings are more prevalent, as in the case of France. Further, bank finance and monitoring is especially important in some countries, such as Germany. Two-tier boards, where the management and supervisory boards are separate entities, are common (e.g., in Germany, Holland, and France). 
Moreover, the governance of continental EU firms often reflects a wider implicit social contract (e.g., in Germany, co-determination rules require half of the supervisory board members to represent labor). At the same time, because executive compensation disclosures tend to be of less uniform quality in many European countries, our EU sample (which consists of companies providing sufficiently transparent disclosure to compute our pay and incentives variables) may be more heavily populated by firms with good corporate governance. Because of these differences, we are limited in our ability to draw inferences about potential reasons for any observed differences in risk-adjusted pay levels between the EU and the US.

We hand-collect CEO compensation and equity incentives data from annual reports and firm accounts for a sample of $40 \mathrm{EU}$ firms for 2003. We select companies from the main European exchanges where complete CEO compensation and option information is available. The small number of firms in the EU sample stems largely from limited disclosure of executive compensation in continental EU compared to the US, especially stock-options and other forms of equity compensation. Because of this, our sample over-represents firms with good disclosures about executive compensation. If firms with better disclosure have superior governance attributes, pay may be relatively lower, and incentives may be relatively higher, compared to non-disclosure firms. Also, because larger firms tend to have more detailed disclosures, our EU sample is comprised of very large firms, considerably larger than the typical firm in our US sample. Our results should be interpreted with the aforementioned caveats in mind. To allow for better comparisons to the US, we use the size and industry propensity-score-matching procedure 
(described above in Tables 2 and 3) to select a sample of 40 US firms that we use to conduct our US vs. EU comparisons. ${ }^{18}$

Descriptive statistics are provided in Table 10. Since our propensity score model includes revenues, the firms in the US and EU samples have relatively similar revenues. US firms have somewhat larger market capitalizations (our propensity score model does not include market capitalization). The US CEOs have higher total pay than the EU CEOs $(\$ 5,075,000$ vs. $\$ 3,284,000$, respectively at the median). At the same time, the US CEOs also hold substantially greater equity incentives than the EU CEOs. The median US CEOs held stock equivalent value of \$25.5 million as compared to \$3.2 million in stock equivalent value for the EU CEOs.

In Tables 11 and 12, we provide US-EU risk-adjusted pay analyses analogous to those in Tables 6 and 7. As in Table 6, controlling for the risk premium substantially reduces the pay differences between US CEOs and EU CEOs. In 2003, the median US CEO received 55\% more pay than the median EU CEO and held about 693\% more equity incentives. Table 11 shows that after deducting our estimate of the expected compensation for holding the median level of incentives, the median risk-adjusted pay is $16 \%$ greater for US CEOs than EU CEOS $(\$ 3,597,000$ vs. $\$ 3,098,000)$. Or, alternatively stated, the $\$ 499,000$ difference in median riskadjusted pay is substantially less than the $\$ 1,791,000$ difference in observed median total pay.

In Table 12, we examine risk-adjusted pay differences when the risk premium adjustment is applied on a CEO by CEO basis. In Panel A, we present the computed risk premium as a percentage of incentives. The lower risk premium for the median US CEO as compared to the median EU CEO (4.88\% to 7.17\%) stems from the fact that our EU sample firms generally have higher stock-return volatility than the matched US sample firms. Panel B of Table 12 shows that

\footnotetext{
${ }^{18}$ Our propensity-score regression model indicates that, in addition to size, our EU firms have greater book-tomarket ratios, lower recent stock returns, lower firm risk, shorter CEO tenure, are less likely to combine the posts of CEO and chair, and have greater debt ratios.
} 
the median risk-adjusted pay in 2003 is \$3,605,000 for the US propensity-score-matched CEOs as compared to $\$ 2,682,000$ for the EU CEOs. The median paired difference is not significantly different from 0. Abstracting away from the magnitude, 21 of 40 (52.25\%) of US CEOs had greater risk-adjusted pay. Thus, as with the US-UK analysis, the results in Tables 11 and 12 suggest that the observed pay difference between the US and EU CEOs may be explained by the large differences in risky equity incentives borne by these individuals.

\section{Concluding remarks}

A growing body of academic research argues that problems with US governance and CEO pay are systemic and that overpayment of CEOs is not limited to a few bad apples, but that all CEOs in the US economy are overpaid. If this conjecture is correct, benchmarking within the US tells us little about whether US executive compensation practices, as a whole, suffer from systemic poor governance and excessive pay. Instead it is necessary to compare US practices with those of other countries where compensation practices ex ante are expected to suffer from these problems to a lesser extent. In this paper, we use the United Kingdom as a benchmark against which to examine whether CEO pay in the United States appears unusually high. These two economies share important governance features, but the UK is generally considered to be less afflicted by problems of excessive executive compensation.

Using US and UK data for 1997 and 2003, we compare US and UK CEO annual pay and incentives. Pay is total annual pay (from cash, stock and option grants, and other pay) and incentives are measured in equivalent stock value (from holdings of stock and stock options). Controlling for firm characteristics, we find that US CEOs have higher compensation and much higher incentives than UK CEOs. In 2003, median pay for a matched sample of US CEOs was 
23\% higher than UK CEO pay and about $118 \%$ higher in 1997. At the same time, US CEO incentives in 2003 were about 4.8 times higher than UK CEO incentives and 6.3 times higher in 1997.

When firms impose greater equity incentives on executives, one expects to observe greater risk premiums paid to those executives. Consequently, we expect that a portion of US CEOs' relatively greater pay is due to their relatively greater equity incentives. The key research question in our paper is whether greater risk premiums can explain some or all of the difference in pay between US and UK CEOs. To estimate risk premiums for US and UK CEOs, we extend the methods in Cai and Vijh (2005) under various assumptions about CEO risk-aversion and outside wealth. Viewing total CEO pay as the sum of pay for CEO effort/ability plus the risk premium to compensate the CEO for bearing incentive risk, we estimate risk-adjusted pay as total pay less the estimated risk premium CEOs receive for holding equity incentives.

For a reasonable range of parameters typical in prior literature, we find that the difference in risk premiums plausibly accounts for differences in pay between US and UK CEOs. Specifically, we find that risk-adjusted pay for US CEOs is not consistently higher than that for UK CEOs (US CEOs have higher risk-adjusted pay in 1997, but UK CEOs have higher riskadjusted pay in 2003). Our analysis of EU CEOs in 2003 offers a similar conclusion that US CEOs, while they have significantly higher pay, do not have significantly higher risk-adjusted pay than their EU counterparts.

We note, however, that while risk premiums offer a potential economic explanation for why US pay is higher than UK and EU pay, it leaves open the question of why US incentives are so much larger than UK and EU incentives. We discuss differences in wealth accumulation as a potential reason for these differences, and suggest that researchers should shift their efforts 
toward better understanding the reasons for differences in incentives between US and CEOs in the UK and in other parts of the world.

We conclude that critics of high US executive pay should give greater consideration to the incentives borne by US CEOs and the risk premiums that executives are likely to require to bear these incentives. Or stated another way, if critics believe that the level of US CEO pay is too high, they also might consider whether they would accept lower UK-style incentives as a trade-off for reductions in pay. However, some of these same critics call for greater "pay-forperformance” and incentives for US CEOs. Our findings suggest that calls for lower pay and greater pay-for-performance may be at odds with each other and may be economically infeasible.

An important caveat is that our conclusions rely on the reasonableness of our risk premium estimates, and if our assumptions about risk-aversion and CEO lack of diversification are invalid, so are our risk premium estimates. For example, if CEOs in both countries had much lower risk-aversion than is assumed in the literature, the estimated risk premium would decrease, and US pay would again appear high compared to UK pay. However, for a fairly broad range of assumptions, risk premiums are likely to remain an important consideration in understanding differences in pay across groups of CEOs with differing levels incentives. At the same time, quantifying the risk-aversion and wealth levels of top executives remains a crucial topic for future research in incentives and governance. A second important caveat is that our conclusions rely on the appropriateness of the choice of the UK and the EU as a benchmark. If UK and EU CEOs are also overpaid, a finding that US CEOs are not more overpaid may be of little comfort. 


\section{References}

Abowd, J., and D. Kaplan, 1999, "Executive Compensation: Six Questions That Need Answering," Journal of Economic Perspectives, 13, 145-168.

Baker, G., and B. Hall, 1998, “CEO incentives and firm size,” Journal of Labor Economics 22: 767-798.

Bebchuk, L.A., and J. Fried, 2004, Pay without Performance: The Unfulfilled Promise of Executive Compensation, Harvard University Press, Cambridge.

Bebchuk, L.A., J. Fried, and D. Walker, 2002, "Managerial Power and Rent Extraction in the Design of Executive Compensation,” University of Chicago Law Review, 69, 751-846.

Becht, M., Franks, J. R., Mayer, C. and Rossi, S., 2006, "Returns to Shareholder Activism Evidence from a Clinical Study of the Hermes U.K. Focus Fund" (December 2006). ECGI - Finance Working Paper No. 138.

Becht, M., Bolton, P. and Röell, A.A., 2002, "Corporate Governance and Control” ECGI Finance Working Paper No. 02/2002. Available at SSRN: http://ssrn.com/abstract=343461 or DOI: 10.2139/ssrn.343461 (revised 2006)

Black, F., and M. Scholes, 1973, “The Pricing of Options and Corporate Liabilities,” Journal of Political Economy, 81, 637-59.

Cai, J., and A.M. Vijh, 2005, "Executive Stock and Option Valuation in a Two State-Variable Framework,” Journal of Derivatives, 12, 9-27.

Conyon, M.J., and K.J. Murphy, 2000, “The prince and the pauper: CEO pay in the US and UK,” Economic Journal, 110, 640-671.

Conyon, M.J., and J. Schwalbach, 1999, "Corporate governance, executive pay and performance in Europe," in J. Carpenter and D. Yermack (eds.), Executive Compensation and Shareholder Value: Theory and Evidence, Kluwer Academic Press, Dordrecht.

Core, J., and W. Guay, 1999, "The use of equity grants to manage optimal equity incentives," Journal of Accounting and Economics, 28, 151-184.

Core, J., W. Guay, 2002, "Estimating the value of employee stock option portfolios and their sensitivities to price and volatility,” Journal of Accounting Research 40, 613-630.

Core, J., W. Guay, and R. Thomas, 2005, "Is U.S. CEO Compensation Inefficient Pay without Performance? A review of Pay without Performance: The Unfulfilled Promise of Executive Compensation,” Michigan Law Review 103 (2005): 1142-1185. 
Core, J., R. Holthausen, and D. Larcker, 1999, "Corporate Governance, Chief Executive Officer Compensation, and Firm Performance,” Journal of Financial Economics, 51, 371-406.

Crystal, G., B.G. Main, and C. O’Reilly, 1994, “Over here and over there: A comparison of top executive pay in the UK and the USA,” International Contributions to Labour Studies, 4, 115-127.

Dahya, J., J.J. McConnell, and N.G. Travlos, 2002, “The Cadbury Committee, corporate performance, and top management turnover,” The Journal of Finance, 57, 461-483.

Edmans, A., Gabaix, X. and Landier, A., 2009, “A multiplicative model of optimal CEO incentives in market equilibrium,” Review of Financial Studies, forthcoming.

Ferri, F. and Maber, D. A., 2008, "Say on Pay Vote and CEO Compensation: Evidence from the UK,” Harvard University Working Paper.

Greenbury, R., 1995, Directors' remuneration: Report of a study group chaired by Sir Richard Greenbury, Gee Publishing, London.

Hall, B., and J. Liebman, 1998, “Are CEOs really paid like bureaucrats?” The Quarterly Journal of Economics, 113, 653-691.

Hall, B., and K.J. Murphy, 2002, “Stock options for undiversified executives,” Journal of Accounting and Economics, 33, 3-42.

Hampel, R., 1998, Committee on Corporate Governance: Final Report, Gee Publishing, London.

Hemmer, T., S. Matsunaga, and T. Shevlin. 1996, “The influence of risk diversification on the early exercise of stock options by executive officers," Journal of Accounting and Economics 21, 45-68.

Huddart, S., and M. Lang. 1996, "Employee stock option exercises: An empirical analysis,” Journal of Accounting and Economics 21, 5-43.

Holmstrom, B., and S.N. Kaplan, 2003, “The State of U.S. Corporate Governance: What's Right and What's Wrong?” ECGI - Finance Working Paper No. 23/2003.

Jensen, M.C., and K.J. Murphy, 1990, “Performance pay and top-management incentives,” Journal of Political Economy, 98, 225-64.

Jensen, M.C., K.J. Murphy, and E.G. Wruck, 2004, "Remuneration: Where We've Been, How We Got to Here, What are the Problems, and How to Fix Them,” Harvard NOM Working Paper No. 04-28; ECGI - Finance Working Paper No. 44/2004. http://ssrn.com/abstract=561305. 
Johnson, S. A. and Y. S. Tian, 2000, "The value and incentive effects of nontraditional executive stock option plans,” Journal of Financial Economics 57: 3-34.

Kaplan, S., 1994a, “Top executive rewards and firm performance: A comparison of Japan and the United States,” Journal of Political Economy, 102, 510-546.

Kaplan, S., 1994b, “Top executives, turnover, and firm performance in Germany,” Journal of Law, Economics and Organization, 10, 142-159.

Main, B. G., 2005, “The ABI Guidelines for Share-Based Incentive Schemes: Setting the hurdle too high?” University of Edinburgh Working Paper.

Mercer Human Resource Consulting, 2005, “2005 worldwide cost of living survey results,” http://www.mercerhr.com/pressrelease/details.jhtml/dynamic/idContent/1142150

Murphy, K.J., 1999, “Executive compensation,” in O. Ashenfelter and D. Card (eds.), Handbook of Labor Economics (Volume 3), Elsevier, North Holland, Amsterdam.

Pratt, J., 1964. Risk aversion in the small and in the large. Econometrica (January), 122-136.

Smith, C.W., and R.L. Watts, 1992, “The Investment Opportunity Set and Corporate Financing, Dividend and Compensation Policies,” Journal of Financial Economics, 32, 263-292. 


\section{Table 1}

Descriptive statistics on full US and UK samples: CEO total pay, incentives, sales and market value in 1997 and 2003

\begin{tabular}{|c|c|c|c|c|c|c|}
\hline & & Year & Average & Median & $\begin{array}{l}\text { Change } \\
\text { in the } \\
\text { average }\end{array}$ & $\begin{array}{l}\text { Change } \\
\text { in the } \\
\text { median }\end{array}$ \\
\hline \multicolumn{7}{|l|}{ Panel A: } \\
\hline Sales $_{\mathrm{t}-1}$ & US & 1997 & $\$ 3,522$ & $\$ 975^{b}$ & & \\
\hline \multirow[t]{3}{*}{ (\$million) } & US & 2003 & $\$ 4,651$ & $\$ 1,121^{b}$ & $32.1 \%$ & $15.0 \%$ \\
\hline & UK & 1997 & $\$ 4,295$ & $\$ 1,779$ & & \\
\hline & UK & 2003 & $\$ 5,155$ & $\$ 1,555$ & $20.0 \%$ & $-12.6 \%$ \\
\hline \multirow[t]{2}{*}{ Ratio US / UK } & & 1997 & 0.82 & 0.55 & & \\
\hline & & 2003 & 0.90 & 0.72 & & \\
\hline \multicolumn{7}{|l|}{ Panel B: } \\
\hline Market Value of & US & 1997 & $\$ 4,273$ & $\$ 1,072^{b}$ & & \\
\hline \multirow[t]{3}{*}{ Equity $_{\mathrm{t}-1}$ (\$million) } & US & 2003 & $\$ 5,791$ & $\$ 1,168^{b}$ & $35.5 \%$ & $9.0 \%$ \\
\hline & UK & 1997 & $\$ 4,985$ & $\$ 2,108$ & & \\
\hline & UK & 2003 & $\$ 4,996$ & $\$ 1,453$ & $0.2 \%$ & $-31.1 \%$ \\
\hline \multirow[t]{2}{*}{ Ratio US / UK } & & 1997 & 0.86 & 0.51 & & \\
\hline & & 2003 & 1.16 & 0.80 & & \\
\hline \multicolumn{7}{|l|}{ Panel C: } \\
\hline Total pay $_{\mathrm{t}}$ & US & 1997 & $\$ 3,739^{a}$ & $\$ 1,959^{a}$ & & \\
\hline \multirow[t]{3}{*}{ (\$thousands) } & US & 2003 & $\$ 4,439^{\mathrm{a}}$ & $\$ 2,521^{\mathrm{a}}$ & $18.7 \%$ & $28.7 \%$ \\
\hline & UK & 1997 & $\$ 1,295$ & $\$ 985$ & & \\
\hline & UK & 2003 & $\$ 2,583$ & $\$ 1,891$ & $99.4 \%$ & $92.0 \%$ \\
\hline \multirow[t]{2}{*}{ Ratio US / UK } & & 1997 & 2.89 & 1.99 & & \\
\hline & & 2003 & 1.72 & 1.33 & & \\
\hline \multicolumn{7}{|l|}{ Panel D: } \\
\hline \multirow{4}{*}{$\begin{array}{l}\text { CEO equity } \\
\text { incentives }_{\text {t-1 }} \\
\text { (\$thousands) }\end{array}$} & US & 1997 & $\$ 88,800$ & $\$ 15,807^{\mathrm{a}}$ & & \\
\hline & US & 2003 & $\$ 120,444$ & $\$ 19,555^{\mathrm{a}}$ & $35.6 \%$ & $23.7 \%$ \\
\hline & UK & 1997 & $\$ 7,238$ & $\$ 2,409$ & & \\
\hline & UK & 2003 & $\$ 22,051$ & $\$ 3,806$ & $204.7 \%$ & $58.0 \%$ \\
\hline \multirow[t]{2}{*}{ Ratio US / UK } & & 1997 & 12.27 & 6.56 & & \\
\hline & & 2003 & 5.46 & 5.14 & & \\
\hline
\end{tabular}

${ }^{a}$ US value is significantly greater than UK value at a $5 \%$ level.

${ }^{\mathrm{b}} \mathrm{US}$ value is significantly less than UK value at a $5 \%$ level. 
Note:

The US (UK) sample is 1372 (177) firms in 1997 and 1511 (214) firms in 2003. Sales and Market Value of Equity are measured at the beginning of the respective year. Total Pay for the firm's CEO is defined as the sum of salaries, bonuses, benefits, stock options (valued on the date of the grant using the Black-Scholes formula), restricted stock grants (valued at $100 \%$ of performance contingent awards), and other compensation. CEO equity incentives are in equivalent stock value, and are defined as: (share price) $\times$ (the number of shares held) + (share price) $\times($ option delta) $\times$ (the number of options held). UK pounds sterling denominated data are converted to US dollars using the average \$/£ exchange rate during 1997 (=1.6386) and 2003 (=1.6355). 
Table 2

Determinants of US and UK CEO pay and incentives, and Propensity-Score Matching regression

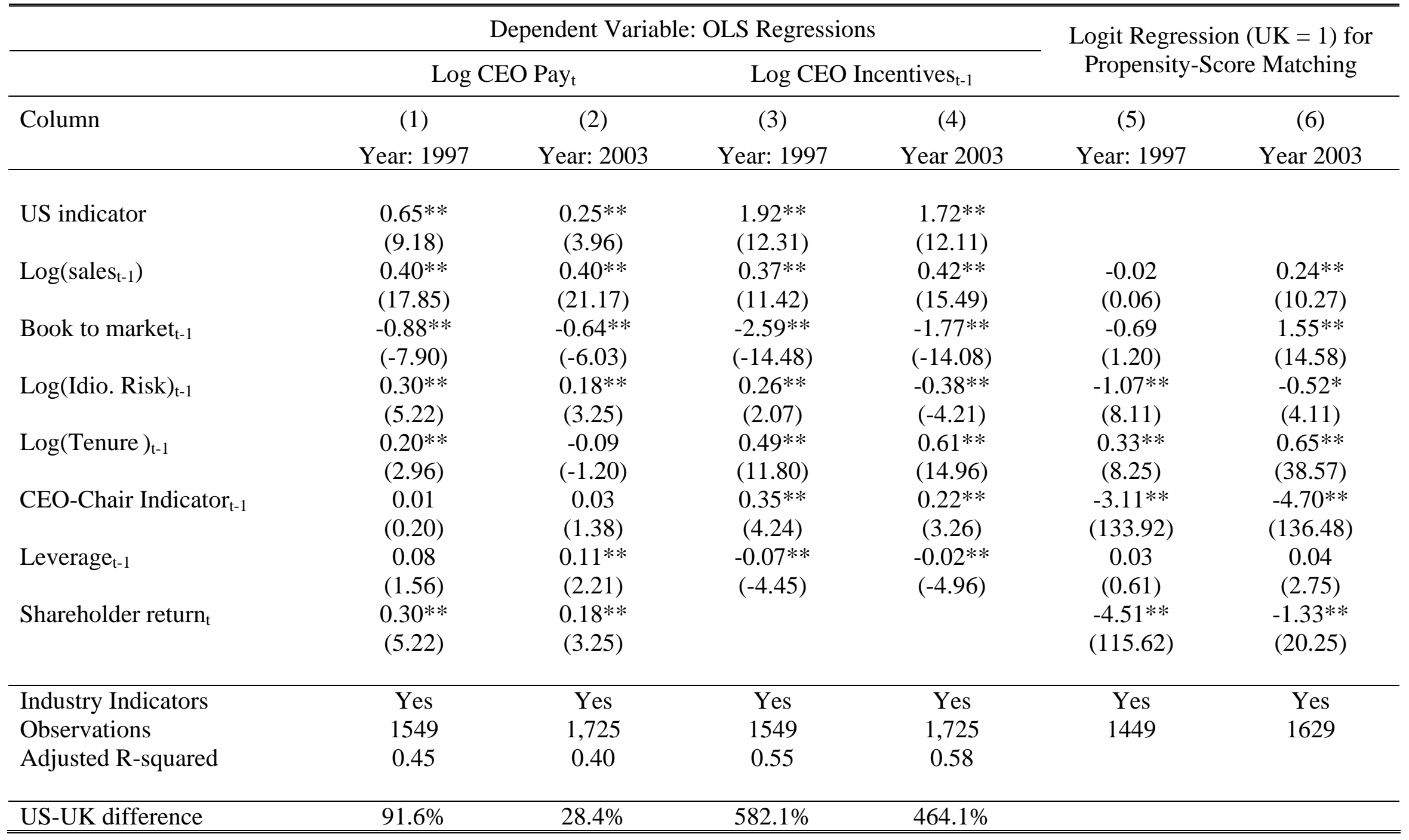


Note:

$\mathrm{A}^{*}$ is significant at $5 \%$, and ${ }^{* *}$ is significant at $1 \%$. T-statistics are given in parentheses for Columns (1)-(4), and are based on Huber-White robust standard errors. Chi-Square statistics are given in parentheses in Columns (5)-(6). Total Pay for the firm's CEO is defined as the sum of salaries, bonuses, benefits, stock options (valued on the date of the grant using the Black-Scholes formula), restricted stock grants (valued at 100\% of performance contingent awards) and other compensation. CEO equity incentives are in equivalent stock value, and are defined as: (share price) $\times($ the number of shares held) $+($ share price $) \times($ option delta) $\times$ (the number of options held). Book-to-market is the ratio of book value of assets to the sum of book value of liabilities plus market value of equity. Idiosyncratic Risk is the standard deviation of the residuals from a market model estimated daily over year t-1.. Tenure is the number of years the CEO has held that position. CEO-Chair Indicator takes the value of 1 if the CEO is also board chair, and zero otherwise. Leverage is the ratio of book value of liabilities to market value of assets. Shareholder Return is the one-year total return to shareholders. Industry dummy variables are computed at the two-digit SIC code level. UK pounds sterling denominated data are converted to US dollars using the average \$/£ exchange rate during 1997 (=1.6386) and 2003 (=1.6355). The US-UK CEO difference is calculated from the US indicator variable as $100 \times\left(\mathrm{e}^{\text {coefficient estimate }}-1\right)$. The 1997 to 2003 change is calculated from the Year=2003 variable as $100 \times\left(\mathrm{e}^{\text {coefficient estimate }}-1\right)$. The logit regressions in Columns (5)-(6) model the probability that a firm is a UK firm as a function of sales, book-to-market, tenure, CEO-Chair indicator, leverage and shareholder return. In the logit regressions, we include only US observations for which we have a UK observation in same industry (because our propensity-score matching procedure matches within industry). 
Table 3

Descriptive statistics on propensity-score-matched US and UK samples: CEO total pay, incentives, sales and market value in 1997 and 2003

\begin{tabular}{|c|c|c|c|c|c|c|}
\hline & & Year & Average & Median & $\begin{array}{c}\text { Change in the } \\
\text { average }\end{array}$ & $\begin{array}{c}\text { Change in the } \\
\text { median }\end{array}$ \\
\hline \multicolumn{7}{|l|}{ Panel A: } \\
\hline Sales $_{\mathrm{t}-1}$ & US & 1997 & $\$ 4,641$ & $\$ 1,578$ & & \\
\hline \multirow[t]{3}{*}{ (\$million) } & US & 2003 & $\$ 5,197$ & $\$ 1,528$ & $12.0 \%$ & $-3.1 \%$ \\
\hline & UK & 1997 & $\$ 4,295$ & $\$ 1,779$ & & \\
\hline & UK & 2003 & $\$ 5,155$ & $\$ 1,555$ & $20.0 \%$ & $-12.6 \%$ \\
\hline \multirow[t]{2}{*}{ Ratio US / UK } & & 1997 & 1.02 & 0.98 & & \\
\hline & & 2003 & 0.92 & 1.08 & & \\
\hline \multicolumn{7}{|l|}{ Panel B: } \\
\hline Market Value of & US & 1997 & $\$ 5,066$ & $\$ 1,926$ & & \\
\hline \multirow[t]{3}{*}{ Equity $_{\mathrm{t}-1}$ (\$million) } & US & 2003 & $\$ 7,486$ & $\$ 1,529$ & $47.8 \%$ & $-20.6 \%$ \\
\hline & UK & 1997 & $\$ 4,985$ & $\$ 2,108$ & & \\
\hline & UK & 2003 & $\$ 4,996$ & $\$ 1,453$ & $0.2 \%$ & $-31.1 \%$ \\
\hline \multirow[t]{2}{*}{ Ratio US / UK } & & 1997 & 1.02 & 0.91 & & \\
\hline & & 2003 & 1.50 & 1.05 & & \\
\hline \multicolumn{7}{|l|}{ Panel C: } \\
\hline Total pay $_{\mathrm{t}}$ & US & 1997 & $\$ 3,890^{\mathrm{a}}$ & $\$ 2,148^{\mathrm{a}}$ & & \\
\hline \multirow[t]{3}{*}{ (\$thousands) } & US & 2003 & $\$ 4,680^{\mathrm{a}}$ & $\$ 2,333^{\mathrm{a}}$ & $20.3 \%$ & $8.6 \%$ \\
\hline & UK & 1997 & $\$ 1,295$ & $\$ 985$ & & \\
\hline & UK & 2003 & $\$ 2,583$ & $\$ 1,891$ & $99.4 \%$ & $92.0 \%$ \\
\hline \multirow[t]{2}{*}{ Ratio US / UK } & & 1997 & 3.00 & 2.18 & & \\
\hline & & 2003 & 1.81 & 1.23 & & \\
\hline \multicolumn{7}{|l|}{ Panel D: } \\
\hline \multirow{4}{*}{$\begin{array}{l}\text { CEO equity } \\
\text { incentives }_{\text {t-1 }} \\
\text { (\$thousands) }\end{array}$} & US & 1997 & $\$ 73,755^{\mathrm{a}}$ & $\$ 15,192^{\mathrm{a}}$ & & \\
\hline & US & 2003 & $\$ 244,115^{\mathrm{a}}$ & $\$ 18,393^{\mathrm{a}}$ & $231.0 \%$ & $21.1 \%$ \\
\hline & UK & 1997 & $\$ 7,238$ & $\$ 2,409$ & & \\
\hline & UK & 2003 & $\$ 22,051$ & $\$ 3,806$ & $204.7 \%$ & $58.0 \%$ \\
\hline \multirow[t]{2}{*}{ Ratio US / UK } & & 1997 & 10.19 & 6.31 & & \\
\hline & & 2003 & 11.07 & 4.83 & & \\
\hline
\end{tabular}

\footnotetext{
${ }^{\mathrm{a}} \mathrm{US}$ value is significantly greater than UK value at a $5 \%$ level.
} 
Note:

The UK sample consists of 177 firms in 1997 and 214 firms in 2003. The US sample also consists of 177 firms in 1997 and 214 firms in 2003, selected using propensity scores developed from the logit regressions reported in Columns (5)(6) of Table 2. Each UK firm is matched within industry to the US firm with the closest propensity score.

Sales and Market Value of Equity are measured at the beginning of the respective year. Total Pay for the firm's CEO is defined as the sum of salaries, bonuses, benefits, stock options (valued on the date of the grant using the BlackScholes formula), restricted stock grants (valued at $100 \%$ of performance contingent awards), and other compensation. CEO equity incentives are in equivalent stock value, and are defined as: (share price) $\times$ (the number of shares held) + (share price) $\times$ (option delta) $\times$ (the number of options held). UK pounds sterling denominated data are converted to US dollars using the average $\$ / £$ exchange rate during 1997 (=1.6386) and 2003 (=1.6355). 


\section{Table 4}

\section{Illustration of incremental pay for incremental incentives for the median CEO}

Median Pay and Incentives (\$thousands)

\begin{tabular}{cccc} 
& & \multicolumn{2}{c}{ Difference: } \\
US - UK \\
\end{tabular}

\section{7}

CEO Pay in 1997

$\$ 2,148$

$\$ 985$

$\$ 1,163$

CEO Equity Incentives at beginning of 1997

$\$ 15,192$

$\$ 2,409$

$\$ 12,783$

Incremental pay per unit of incremental incentive (\%)

$9.10 \%$

2003

CEO Pay in 2003

$\$ 2,333$

$\$ 1,891$

$\$ 442$

CEO Equity Incentives at beginning of 2003

$\$ 18,393$

$\$ 3,806$

$\$ 14,587$

Incremental pay per unit of incremental incentive (\%)

$3.03 \%$

Note:

Incremental pay per unit of incremental incentive in the last column is computed as the difference in pay divided by the difference in incentives, and is expressed as a percentage.

The UK sample consists of 177 firms in 1997 and 214 firms in 2003. The US sample consists of 177 firms in 1997 and 214 firms in 2003, selected using the propensity-score-matching procedure described in Tables 2 and 3. CEO pay is defined as the sum of salaries, bonuses, benefits, stock options (valued on the date of the grant using the Black-Scholes formula), restricted stock grants (valued at $100 \%$ of performance contingent awards) and other compensation. Incentives are the dollar change in CEO firm-specific wealth from a one percent change in the stock price, and are measured at the beginning of the year. UK pounds sterling denominated data are converted to US dollars using the average \$/£ exchange rate during each of the years 1997 (=1.6386) and 2003 (=1.6355). 


\section{Table 5}

\section{Risk premium for holding firm equity}

\begin{tabular}{ccc} 
& \multicolumn{2}{c}{$\%$ of wealth in firm equity } \\
\cline { 2 - 3 } Relative risk-aversion & $50 \%$ & $67 \%$ \\
\hline 2 & $5.8 \%$ & $7.6 \%$ \\
3 & $8.5 \%$ & $11.0 \%$
\end{tabular}

Note:

This table shows the risk premium as a \% of incentives for various levels of risk-aversion and \% of wealth in firm stock. The risk premium is derived by solving:

\section{$E[U($ wealth unconstrained $)]=$ $E[U$ (wealth constrained to firm equity, outside wealth, risk premium) $]$}

The expression on the left side is the utility the executive receives from investing his wealth in a utility-maximizing combination of the risk-free asset and the market portfolio. The expression on the right side is the utility the executive receives when he is constrained to invest some proportion of his starting wealth in firm equity, and the remainder in a utility-maximizing combination of the risk-free asset and the market portfolio. The executive holds the positions for one year. The risk premium is assumed to be paid at the end of the year, and is the amount that sets the two sides equal. A percentage risk premium of 5.8\%, for example, means that, if the CEO had \$1 million in firm equity, he would need to receive $\$ 58,000$ in extra pay to compensate for the additional risk.

The executive is assumed to hold all stock (no options). Returns on the stock and on the market portfolio are assumed to be jointly lognormal, and to follow the capital asset pricing model. The market is assumed to have an $11 \%$ expected return and $20 \%$ volatility, and the risk-free rate is assumed to be $5 \%$. The stock is assumed to have a beta of 1 , an $11 \%$ expected return, and $40 \%$ volatility. 
Table 6

Implied risk-adjusted pay for the median CEO

Median Pay and Incentives (\$thousands)

\begin{tabular}{lccc} 
& US & UK & US/UK \\
\hline Relative risk-aversion & 2 & 2 & 1.00 \\
Wealth in firm (\%) & $50 \%$ & $50 \%$ & 1.00
\end{tabular}

1997

$\begin{array}{lccc}\text { CEO Pay in 1997 } & \$ 2,148 & \$ 985 & 2.18 \\ & & & \\ \text { CEO Equity Incentives at beginning of 1997 } & \$ 15,192 & \$ 2,409 & 6.31 \\ \text { Implied CEO Total Wealth } & \$ 30,384 & \$ 4,818 & 6.31 \\ \text { Risk premium (5.8\% of incentives) } & \$ 881 & \$ 140 & 6.31 \\ \text { Implied risk-adjusted pay } & \$ 1,267 & \$ 845 & 1.50\end{array}$

2003

$\begin{array}{lccc}\text { CEO Pay in 2003 } & \$ 2,333 & \$ 1,891 & 1.23 \\ & & & \\ \text { CEO Equity Incentives at beginning of 2003 } & \$ 18,393 & \$ 3,806 & 4.83 \\ \text { Implied CEO Total Wealth } & \$ 36,787 & \$ 7,612 & 4.83 \\ \text { Risk premium (5.8\% of incentives) } & \$ 1,067 & \$ 221 & 4.83 \\ \text { Implied risk-adjusted pay } & \$ 1,266 & \$ 1,670 & 0.76\end{array}$

Note:

Implied risk-adjusted pay is computed as pay minus the risk premium. The risk premium is assumed to be $5.8 \%$ of incentive (assuming relative risk-aversion of 2.0 and $50 \%$ of wealth in firm equity, and using the calculations shown in Table 5). Implied CEO total wealth, under the assumption of $50 \%$ of wealth in firm equity, and the simplifying assumption that all incentives come from stock, is (equity incentives)/.50.

The UK sample consists of 177 firms in 1997 and 214 firms in 2003 . The UK sample consists of 177 firms in 1997 and 214 firms in 2003. The US sample consists of 177 firms in 1997 and 214 firms in 2003, selected using the propensityscore-matching procedure described in Tables 2 and 3. CEO pay is defined as the sum of salaries, bonuses, benefits, stock options (valued on the date of the grant using the Black-Scholes formula), restricted stock grants (valued at 100\% of performance contingent awards) and other compensation. CEO equity incentives are in equivalent stock value, and are defined as: (share price) $\times$ (the number of shares held) $+($ share price $) \times($ option delta $) \times($ the number of options held), measured at the beginning of the year. UK pounds sterling denominated data are converted to US dollars using the average \$/£ exchange rate during 1997 (=1.6386) and 2003 (=1.6355). 


\section{Table 7}

\section{Implied CEO-specific risk-adjusted pay}

\section{Panel A: Computed risk premium as \% of incentives}

\begin{tabular}{lcccccc}
\hline \hline Country & $\mathrm{N}$ & Average & $\begin{array}{c}25^{\text {th }} \\
\text { percentile }\end{array}$ & Median & $\begin{array}{c}75^{\text {th }} \\
\text { percentile }\end{array}$ \\
\hline \multirow{2}{*}{1997} & UK & 177 & $4.01 \%$ & $2.69 \%$ & $3.86 \%$ & $5.05 \%$ \\
& US & 177 & $4.11 \%$ & $2.53 \%$ & $3.68 \%$ & $5.13 \%$ \\
2003 & UK & 214 & $8.37 \%$ & $5.05 \%$ & $7.21 \%$ & $8.98 \%$ \\
& US & 214 & $8.78 \%$ & $4.84 \%$ & $6.59 \%$ & $10.52 \%$ \\
\hline \hline
\end{tabular}

\section{Panel B: Implied risk-adjusted pay (\$thousands)}

\begin{tabular}{|c|c|c|c|c|c|c|c|}
\hline & Country & $\mathrm{N}$ & $\begin{array}{c}\text { Average } \\
\text { (All values) } \\
(1) \\
\end{array}$ & $\begin{array}{c}\text { Average } \\
\text { (Negative } \\
\text { Values set to } \\
0) \\
(2) \\
\end{array}$ & $\begin{array}{c}25^{\text {th }} \\
\text { percentile } \\
\text { (3) }\end{array}$ & $\begin{array}{c}\text { Median } \\
\text { (4) }\end{array}$ & $\begin{array}{c}75^{\text {th }} \\
\text { percentile } \\
(5)\end{array}$ \\
\hline \multirow[t]{3}{*}{1997} & UK & 177 & $\$ 1,008$ & $\$ 1,087$ & $\$ 481$ & $\$ 808$ & $\$ 1,334$ \\
\hline & US & 177 & $\$ 1,406$ & $\$ 2,595$ & $\$ 458$ & $\$ 1,316$ & $\$ 2,991$ \\
\hline & $\begin{array}{c}\text { US-UK } \\
\%(U S>U K)\end{array}$ & 177 & $\begin{array}{c}\$ 398 \\
58.2 \%\end{array}$ & -- & $-\$ 759$ & $\$ 540^{\mathrm{a}}$ & $\$ 2,211$ \\
\hline \multirow[t]{3}{*}{2003} & UK & 214 & $\$ 936$ & $\$ 2,086$ & $\$ 905$ & $\$ 1,564$ & $\$ 2,728$ \\
\hline & US & 214 & $-\$ 11,561$ & $\$ 2,651$ & $\$ 16$ & $\$ 885$ & $\$ 2,528$ \\
\hline & $\begin{array}{c}\text { US-UK } \\
\%(U S>U K)\end{array}$ & 214 & $\begin{array}{c}-\$ 12,497 \\
39.3 \%\end{array}$ & -- & $-\$ 2,443$ & $-\$ 695^{b}$ & $\$ 1,331$ \\
\hline
\end{tabular}

\footnotetext{
${ }^{a}$ US value is significantly greater than UK value at a $5 \%$ level.

${ }^{\mathrm{b}}$ US value is significantly lower than UK value at a $5 \%$ level.

Note:

The UK sample consists of 177 firms in 1997 and 214 firms in 2003. The US sample consists of 177 firms in 1997 and 214 firms in 2003, selected using the propensity-score-matching procedure described in Tables 2 and 3. Implied riskadjusted pay (expressed in thousands of dollars) is computed as total pay minus the risk premium. The risk premium is estimated using Equation (1) above assuming that the CEO has relative risk-aversion of 2 and 50\% of his wealth outside the firm. Inputs into the calculation are the CEO's beginning-of-year stock and option portfolio, the firm's beta and volatility, an assumed market volatility of $20 \%$, a risk-free rate of $5 \%$, and a market risk premium of $6 \%$. UK pounds sterling denominated data are converted to US dollars using the average $\$ / £$ exchange rate during 1997 (=1.6386) and 2003 (=1.6355).
} 
Table 8

Differences in UK-US CEO pay and incentives: Relations to Competition and Globalization

\begin{tabular}{cccc}
\hline \hline & \multicolumn{3}{c}{ Median Regressions: Dependent Variable (000’s) } \\
\hline & $\begin{array}{c}\text { US-UK Diff in } \\
\text { CEO Pay }\end{array}$ & $\begin{array}{c}\text { US-UK Diff in } \\
\text { CEO Incentives }\end{array}$ & $\begin{array}{c}\text { US-UK Diff in CEO } \\
\text { Risk-Adjusted Pay }\end{array}$ \\
\hline Column & $(1)$ & $(2)$ & $(3)$ \\
\hline Intercept & $1.06^{* *}$ & $9.74^{* *}$ & $0.49 *$ \\
& $(3.40)$ & $(3.83)$ & $(1.95)$ \\
Hirschman-Herfindahl Index & 2.51 & 23.73 & 3.47 \\
UK Foreign Exchange & $(0.44)$ & $(0.40)$ & $(0.71)$ \\
Listing Indicator & $-1.42^{*}$ & $11.44^{*}$ & -1.06 \\
& $(-2.12)$ & $(1.79)$ & $(-1.44)$ \\
Year 2003 Indicator & $-0.82^{*}$ & -0.27 & $-1.25^{* *}$ \\
& $(-2.57)$ & $(-0.09)$ & $(-4.14)$ \\
Pseudo R-squared & 0.02 & 0.01 & 0.01 \\
\hline \hline
\end{tabular}

Note:

$\mathrm{A}^{*}$ is significant at $5 \%$, and ${ }^{* *}$ is significant at $1 \%$. The UK sample consists of 391 firm-years (177 firm-years in 1997 and 214 firm-years in 2003). The US sample also consists of 391 firm-years, selected using propensity scores developed from the logit regressions reported in Columns (5)-(6) of Table 2. Each UK firm is matched within industry to the US firm with the closest propensity score.

UK Foreign Exchange Listing Indicator is an indicator variable for whether the UK firm was listed on any US exchange, as a proxy for the degree of exposure the UK firm has to global markets. The Hirschman-Herfindahl Index is the sum of squared market shares within a 2-digit SIC industry. The market share is firm sales as a fraction of total industry sales. 
Table 9

Implied risk-adjusted pay for the median CEO - Sensitivity analysis UK CEOs assumed more risk-averse and less diversified than US CEOs

Median Pay and Incentives (\$thousands)

\begin{tabular}{lccc} 
& US & UK & US/UK \\
\hline Relative risk-aversion & & & \\
Wealth in firm (\%) & 2 & 3 & 0.67 \\
& $50 \%$ & $67 \%$ & 0.67
\end{tabular}

1997

CEO Pay in 1997

CEO Equity Incentives at beginning of 1997

Implied CEO Total Wealth

Risk premium (5.8\% for US and $11.0 \%$ for UK)

Implied risk-adjusted pay

2003

CEO Pay in 2003

CEO Equity Incentives at beginning of 2003 Implied CEO Total Wealth

Risk premium (5.8\% for US and $11.0 \%$ for UK)

Implied risk-adjusted pay
$\$ 2,148$

$\$ 15,192$

$\$ 30,384$

$\$ 881$

$\$ 1,267$

$\$ 2,333$

$\$ 1,891$

1.23

$\$ 18,393$

$\$ 36,787$

$\$ 3,806$

$\$ 5,681$

4.83

6.48

$\$ 1,067$

$\$ 419$

2.55

$\$ 1,266$

$\$ 1,472$

0.86

\footnotetext{
Note:

The UK sample consists of 177 firms in 1997 and 214 firms in 2003. The US sample consists of 177 firms in 1997 and 214 firms in 2003, selected using the propensity-score-matching procedure described in Tables 2 and 3 . Implied riskadjusted pay is computed as pay minus the risk premium. The risk premium is assumed to be $5.8 \%$ of incentives for US CEOs (assuming relative risk-aversion of 2.0 and $50 \%$ of wealth in firm equity and using the calculations shown in Table 5), and is assumed to be $11.0 \%$ of incentives for the UK CEOs (assuming relative risk-aversion of 3.0 and $67 \%$ of wealth in firm equity and using the calculations shown in Table 5). Implied CEO total wealth for US CEOs, under the assumption of $50 \%$ of wealth in firm equity, and the simplifying assumption that all incentives come from stock, is (equity incentives)/.50, and for UK CEOs, under the assumption of $67 \%$ of wealth in firm equity, and the simplifying assumption that all incentives come from stock, is (equity incentives)/.67.
}

CEO pay is defined as the sum of salaries, bonuses, benefits, stock options (valued on the date of the grant using the Black-Scholes formula), restricted stock grants (valued at $100 \%$ of performance contingent awards) and other compensation. CEO equity incentives are in equivalent stock value, and are defined as: (share price) $\times($ the number of shares held $)+($ share price $) \times($ option delta $) \times($ the number of options held), measured at the beginning of the year. UK pounds sterling denominated data are converted to US dollars using the average \$/£ exchange rate during 1997 (=1.6386) and 2003 (=1.6355). 
Table 10

Descriptive statistics EU sample and propensity-score-matched US sample: CEO total pay, incentives, sales and market value in 2003

\begin{tabular}{|c|c|c|c|}
\hline & & Average & Median \\
\hline \multicolumn{4}{|l|}{ Panel A: } \\
\hline \multirow[t]{2}{*}{ Sales $_{\mathrm{t}-1}$ (\$million) } & US & $\$ 20,909$ & $\$ 17,611$ \\
\hline & EU & $\$ 24,979$ & $\$ 18,590$ \\
\hline Ratio US / EU & & 0.84 & 0.95 \\
\hline \multicolumn{4}{|l|}{ Panel B: } \\
\hline Market Value of & US & $\$ 28,934$ & $\$ 14,151$ \\
\hline Equity $_{\mathrm{t}-1}($ \$million$)$ & EU & $\$ 18,512$ & $\$ 12,163$ \\
\hline Ratio US / EU & & 1.56 & 1.16 \\
\hline \multicolumn{4}{|l|}{ Panel C: } \\
\hline \multirow{2}{*}{ Total payt (\$thousands) } & US & $\$ 8,038^{\mathrm{a}}$ & $\$ 5,075^{a}$ \\
\hline & EU & $\$ 4,982$ & $\$ 3,284$ \\
\hline Ratio US / EU & & 1.61 & 1.55 \\
\hline \multicolumn{4}{|l|}{ Panel D: } \\
\hline CEO equity incentives $\mathrm{t}_{\mathrm{t}-1}$ & US & $\$ 375,937^{\mathrm{a}}$ & $\$ 25,478^{a}$ \\
\hline (\$thousands) & EU & $\$ 5,858$ & $\$ 3,213$ \\
\hline Ratio US / EU & & 64.17 & 7.93 \\
\hline
\end{tabular}

${ }^{a}$ US value is significantly greater than EU value at a $5 \%$ level.

Note:

The EU sample consists of 40 firms in 2003. The US sample also consists of 40 firms in 2003, selected using propensity scores developed from a logit regression similar to those reported in Columns (5)-(6) of Table 2. Each EU firm is matched within industry to the US firm with the closest propensity score. Sales and Market Value of Equity are measured at the beginning of the respective year. Total Pay for the firm's CEO is defined as the sum of salaries, bonuses, benefits, stock options (valued on the date of the grant using the Black-Scholes formula), restricted stock grants (valued at $100 \%$ of performance contingent awards), and other compensation. CEO equity incentives are in equivalent stock value, and are defined as: (share price) $\times($ the number of shares held) $+($ share price $) \times($ option delta $) \times$ (the number of options held). EU currency denominated data are converted to US dollars using the average exchange rate during 2003. 
Table 11

\section{EU and US Propensity Score Matched Sample}

Panel A Incremental pay for incremental incentive for the median CEO

\begin{tabular}{lccc}
\hline \hline & \multicolumn{2}{c}{ Median Pay and Incentives (\$thousands) } \\
& US & EU & $\begin{array}{c}\text { Difference: } \\
\text { US - EU }\end{array}$ \\
\hline CEO Pay in 2003 & $\$ 5,075$ & $\$ 3,284$ & $\$ 1,791$ \\
CEO Equity Incentives at beginning of 2003 & $\$ 25,478$ & $\$ 3,213$ & $\$ 22,265$ \\
Incremental pay per unit of incremental incentive & & & $8.04 \%$ \\
\hline \hline
\end{tabular}

\section{Panel B Implied risk-adjusted pay for the median CEO}

\begin{tabular}{lccc}
\hline \hline & & & \\
& & & \\
& US & EU & US/EU \\
\hline & & & \\
CEO Pay in 2003 & $\$ 5,075$ & $\$ 3,284$ & 1.55 \\
CEO Equity Incentives at beginning of 2003 & $\$ 25,478$ & $\$ 3,213$ & 7.93 \\
Implied CEO Total Wealth & $\$ 50,955$ & $\$ 6,425$ & 7.93 \\
Risk premium (5.8\% of incentives) & $\$ 1,478$ & $\$ 186$ & 7.93 \\
Implied risk-adjusted pay & $\$ 3,597$ & $\$ 3,098$ & 1.16 \\
\hline \hline
\end{tabular}

Note:

Implied risk-adjusted pay is computed as pay minus the risk premium. The risk premium is assumed to be $5.8 \%$ of incentive (assuming relative risk-aversion of 2.0 and $50 \%$ of wealth in firm equity, and using the calculations shown in Table 5). Implied CEO total wealth, under the assumption of $50 \%$ of wealth in firm equity, and the simplifying assumption that all incentives come from stock, is (equity incentives)/.50.

Total Pay for the firm's CEO is defined as the sum of salaries, bonuses, benefits, stock options (valued on the date of the grant using the Black-Scholes formula), restricted stock grants (valued at $100 \%$ of performance contingent awards), and other compensation. CEO equity incentives are in equivalent stock value, and are defined as: (share price) $\times$ (the number of shares held $)+($ share price $) \times($ option delta $) \times$ (the number of options held). EU currency denominated data are converted to US dollars using the average exchange rate during 2003. 
Table 12

Implied CEO-specific risk-adjusted pay

EU and US Propensity Score-Matched Sample

Panel A: Computed risk premium as \% of incentives

\begin{tabular}{ccccccc}
\hline \hline Country & $\mathrm{N}$ & Average & $\begin{array}{c}25^{\text {th }} \\
\text { percentile }\end{array}$ & Median & $\begin{array}{c}75^{\text {th }} \\
\text { percentile }\end{array}$ \\
\hline \multirow{2}{*}{2003} & US & 40 & 8.22 & 3.65 & 4.88 & 9.17 \\
& EU & 40 & 7.87 & 4.44 & 7.17 & 9.48 \\
\hline \hline
\end{tabular}

\section{Panel B: Implied risk-adjusted pay (\$thousands)}

\begin{tabular}{|c|c|c|c|c|c|c|c|}
\hline & Country & $\mathrm{N}$ & $\begin{array}{l}\text { Average } \\
\text { (All } \\
\text { values) }\end{array}$ & $\begin{array}{l}\text { Average } \\
\text { (Negative } \\
\text { Values } \\
\text { set to 0) }\end{array}$ & $\begin{array}{c}25^{\text {th }} \\
\text { percentile }\end{array}$ & Median & $\begin{array}{c}75^{\text {th }} \\
\text { percentile }\end{array}$ \\
\hline 2003 & $\begin{array}{c}\text { US } \\
\text { EU } \\
\text { US-EU } \\
\%(U S>E U)\end{array}$ & $\begin{array}{l}40 \\
40 \\
40\end{array}$ & $\begin{array}{c}-10,654 \\
5,354 \\
-\$ 15,175 \\
52.5 \%\end{array}$ & $\begin{array}{l}5,354 \\
4,532\end{array}$ & $\begin{array}{c}903 \\
2,037 \\
-\$ 3,218\end{array}$ & $\begin{array}{c}3,605 \\
2,682 \\
\$ 1,061\end{array}$ & $\begin{array}{c}8,557 \\
4,717 \\
\$ 5,309\end{array}$ \\
\hline
\end{tabular}

Note:

The EU sample consists of 40 firms in 2003. The US sample consists of 40 firms in 2003, selected using propensity scores developed from logit regressions similar to those reported in Columns (5)-(6) of Table 2. Each EU firm is matched within industry to the US firm with the closest propensity score. Implied risk-adjusted pay (expressed in thousands of dollars) is computed as total pay minus the risk premium. The risk premium is estimated using Equation (1) above assuming that the CEO has relative risk-aversion of 2 and $50 \%$ of his wealth outside the firm. Inputs into the calculation are the CEO's beginning-of-year stock and option portfolio, the firm's beta and volatility, an assumed market volatility of $20 \%$, a risk-free rate of $5 \%$, and a market risk premium of $6 \%$. EU currency denominated data are converted to US dollars using the average exchange rate during 2003. 